\title{
Plant Tolerance to Drought Stress in the Presence of Supporting Bacteria and Fungi: An Efficient Strategy in Horticulture
}

\author{
Agnieszka Hanaka ${ }^{1, * \mathbb{D}}$, Ewa Ozimek ${ }^{2}$, Emilia Reszczyńska ${ }^{1}$, Jolanta Jaroszuk-Ściseł ${ }^{2}$ and Maria Stolarz $^{1}$ (D) \\ 1 Department of Plant Physiology and Biophysics, Faculty of Biology and Biotechnology, \\ Institute of Biological Sciences, Maria Curie-Skłodowska University, Akademicka 19, 20-031 Lublin, Poland; \\ emilia.reszczynska@umcs.pl (E.R.); maria.stolarz@umcs.pl (M.S.) \\ 2 Department of Industrial and Environmental Microbiology, Faculty of Biology and Biotechnology, \\ Institute of Biological Sciences, Maria Curie-Skłodowska University, Akademicka 19, 20-031 Lublin, Poland; \\ ewa.ozimek@umcs.pl (E.O.); jolanta.jaroszuk-scisel@umcs.pl (J.J.-S.) \\ * Correspondence: agnieszka.hanaka@umcs.pl
}

Citation: Hanaka, A.; Ozimek, E.; Reszczyńska, E.; Jaroszuk-Ściseł, J.; Stolarz, M. Plant Tolerance to Drought Stress in the Presence of Supporting Bacteria and Fungi: An Efficient Strategy in Horticulture. Horticulturae 2021, 7, 390. https:/ / doi.org/10.3390/horticulturae7100390

Academic Editor: Alessandra Francini

Received: 1 September 2021

Accepted: 5 October 2021

Published: 11 October 2021

Publisher's Note: MDPI stays neutral with regard to jurisdictional claims in published maps and institutional affiliations.

Copyright: (c) 2021 by the authors. Licensee MDPI, Basel, Switzerland. This article is an open access article distributed under the terms and conditions of the Creative Commons Attribution (CC BY) license (https:// creativecommons.org/licenses/by/ $4.0 /)$.
Abstract: Increasing temperature leads to intensive water evaporation, contributing to global warming and consequently leading to drought stress. These events are likely to trigger modifications in plant physiology and microbial functioning due to the altered availability of nutrients. Plants exposed to drought have developed different strategies to cope with stress by morphological, physiological, anatomical, and biochemical responses. First, visible changes influence plant biomass and consequently limit the yield of crops. The presented review was undertaken to discuss the impact of climate change with respect to drought stress and its impact on the performance of plants inoculated with plant growth-promoting microorganisms (PGPM). The main challenge for optimal performance of horticultural plants is the application of selected, beneficial microorganisms which actively support plants during drought stress. The most frequently described biochemical mechanisms for plant protection against drought by microorganisms are the production of phytohormones, antioxidants and xeroprotectants, and the induction of plant resistance. Rhizospheric or plant surface-colonizing (rhizoplane) and interior (endophytic) bacteria and fungi appear to be a suitable alternative for drought-stress management. Application of various biopreparations containing PGPM seems to provide hope for a relatively cheap, easy to apply and efficient way of alleviating drought stress in plants, with implications in productivity and food condition.

Keywords: climate change; drought stress; biopreparations; plant stimulation; plant growth-promoting microorganisms

\section{Introduction}

The horticulture system is affected by various abiotic and biotic stresses which directly and indirectly influence soil fertility, plant health and crop yield [1-3]. These stresses result in the loss of soil microbial diversity, soil fertility and availability of nutrients [4]. The condition of the soil under drought strictly corresponds to plant performance, showing consequences in plant morphology, anatomy, physiology, and biochemistry. With reduction in seed germination and seedling growth, plant height, nutrition and biomass are weakened resulting in yield limitation. The huge variety of changes taking place in horticultural plants and the mechanisms of counteracting stress they produce result from a very wide range of horticultural plant species, including types of crops such as those distinguished by the International Society for Horticultural Science (ISHS): (1) tree, bush and perennial fruits, (2) perennial bush and tree nuts, (3) vegetables (roots, tubers, shoots, stems, leaves, fruits and flowers of edible and mainly annual plants), (4) medicinal and aromatic plants, (5) ornamental plants, (6) trees, shrubs, turf and ornamental grasses propagated and produced in nurseries for use in landscaping or for establishing fruit orchards or other crop production units [5]. Facing the current, rapid climate changes, the cultivation of 
plants is strongly affected by abiotic stresses, which additionally intensify the influence of biotic factors such as pests causing serious plant infections [4]. In this dramatic situation, plant associations with rhizospheric $[6,7]$ and endophytic $[8,9]$ microorganisms colonizing the rhizoplane, rhizosphere and plant tissues should be considered as the main stress relievers [10-14]. Three types of effects of microorganisms associated with plants are distinguished: beneficial, deleterious and neutral ones. Based on the positive effects of microbes, two main groups are listed, plant growth-promoting rhizobacteria (PGPR) or more generally, plant growth-promoting bacteria (PGPB) and plant growth-promoting fungi (PGPF) [14-19]. All mentioned groups of microorganisms can serve as biocontrol agents, biofertilizers, phytostimulators and phytoremediators [2,12,20-22].

The most frequently described biochemical mechanisms of plant protection against drought by microorganisms are the production of phytohormones, antioxidants and xeroprotectants [23]. Trehalose can act as xeroprotectant triggering the plant-defense system to counteract the damage caused by drought. It has been shown that microorganisms with tolerance to desiccation have the ability to protect some plants from drought. It seems to be dependent on the microorganism's ability to regulate the concentration of trehalose in the plant as a signal of drying damage.

In horticultural production, plant-microbe interactions should be considered the main factor of plant growth, protection against abiotic stresses and resistance against adverse conditions [24,25] (e.g., in arid and semiarid areas), and these interactions could also be beneficial in alleviating drought stress in plants [26]. Profound knowledge about the mechanisms of plant-microbe interactions can offer several strategies to increase plant productivity in an environmentally friendly manner [27]. Therefore, in the increasing market for plant growth-promoting products, it is important to develop a successful strategy for microorganism screening [28]. Furthermore, the European Green Deal (EGD), provided by the European Commission in December 2019, is currently focused on the application of natural products in agriculture and horticulture instead of chemical plantprotection products. To cope with this idea, new efficient biological ingredients in the face of changing climate are desired. Nowadays, the most significant consequence of climate change is drought stress [29].

To deal with severe drought stress in the near future, it is strictly necessary to determine the interactions, mechanisms and signaling pathways responsible for increased drought tolerance in terrestrial organisms. The concept of drought and water deficit is difficult to define, but the literature data [30-32] indicate that drought can be defined as a state of the total water capacity being within the range of $12-20 \%$ for a period of 16 days. Moreover, the drought state can achieve at least two degrees—mild and severe [33] — while the water deficit [34] refers to the state of water capacity falling below $30 \%$. To handle the drought effect, plants can be supported by both microorganisms inhabiting the rhizoplane (i.e., those adhering to the surface of the roots) and rhizosphere (i.e., living at a further distance within the root secretions) [34,35], as well as endophytic microorganisms inhabiting the inside of the root [36]. The application of plant growth-promoting microorganisms seems to provide hope for a cheap, easy to apply and efficient way of alleviating drought stress in plants with implications in productivity and food condition. The presented review was undertaken to discuss the impact of climate change with respect to drought stress, and to emphasize that modifications in microorganisms composition and their traits should indicate new solutions in the search for efficient compounds of biopreparations supporting plant growth.

\section{Climate Change}

Global climate change is expected to be considerably critical over the century, leading to influences on various parameters of the environment [17]. Not only atmospheric $\mathrm{CO}_{2}$ concentrations derived from natural and anthropogenic sources, but also surface temperatures will be increasing gradually, likely from 1.0 to $5.7^{\circ} \mathrm{C}$ by the end of this century [37]. Moreover, some regions, such as the Eastern Mediterranean and Middle East (EMME), 
have been classified as a climate "global hot-spot". In the EMME, the temperature is predicted to increase from 3.5 to $7{ }^{\circ} \mathrm{C}$ by the end of the century [38]. Additionally, it is anticipated that rising air temperatures will increase the frequency of extreme weather disasters such as heat waves, drought and heavy precipitation occurrence to a level that has never been monitored before [37]. These strongly temperature-dependent climate changes, combined with water scarcity, will lead to enhanced drought throughout the globe, hurting whole ecosystems and different organisms, including the distribution of plants and microorganisms [17].

In climate studies, calculations concerning crop evapotranspiration are also important [17]. For instance, in South East Europe, the mean annual crop evapotranspiration in the period 1991-2020 reached from $56 \mathrm{~mm}$ to $1297 \mathrm{~mm}$, while averages for the future 30 years (between 2021 and 2050), are expected to vary from $59 \mathrm{~mm}$ to $1410 \mathrm{~mm}$ [17]. These predictions consider the impact of future climate warming. Global warming increases water evaporation and consequently leads to drought stress [39]. High temperature is the crucial factor in melting glaciers and increasing the sea level [8]. The changes in polar and subpolar climate zones also correspond with climate warming [40-42].

Climate change results in altered environmental conditions and negative effects on natural ecosystems, which are likely to trigger modifications in plant physiology [43] and microbial functioning [44] based on the availability of nutrients [4] or signal compounds [2]. It is certain that not only plants, but also plant-associated microorganisms might be remarkably changed in abundance, diversity and activity [44,45]. Both increased temperature and drought may activate correspondent adjustments in plants and microorganisms and their mutual interactions [17]. The adaptational challenges of horticultural plants are not only associated with long-term average climate change, but also with the short-term changes driven by weather extremes and interannual fluctuations [46]. Drought-related cereal production losses are increasing by more than $3 \% \mathrm{yr}^{-1}$ [46]. In the face of the continuous raise of the world population to an estimated nine billion by 2050 [47], withstanding drought stress according to sustainable agriculture/horticulture is a challenge for the $21 \mathrm{st}$ century [48].

\section{Plants under Drought Stress}

Drought is an uncontrolled stress which affects almost all stages of plant growth and development directly or indirectly [43]. Most of the drought effects on plants are associated with high temperature. Physiological processes occur mostly in temperatures ranging from $0{ }^{\circ} \mathrm{C}$ to $40^{\circ} \mathrm{C}$. However, the optimal temperatures for the different stages of growth and development are narrower and strongly depend on the species and ecological origin [1,49].

Plants exposed to drought stress develop numerous responses in different areas, from morphological and physiological mechanisms to anatomical and biochemical or molecular ones $[1,39,50]$ (Figure 1).

Four types of morphological and physiological response strategies to drought stress are highlighted, i.e., tolerance, avoidance, escape and recovery [51] (Figure 2). Tolerance is defined as the plant's ability to resist dehydration using osmoprotectants [52]. Avoidance is based on the undisturbed occurrence of physiological processes (such as stomata regulation, root system development). Escape is the adjustment of the plant's life cycle by shortening of the life cycle to avoid drought stress. Recovery is the ability of a plant to restart growth after the exposure to the extreme drought stress [53].

The morphological features of drought stress include limited seed germination and seedling growth, reduced size, area and number of leaves, restricted number of stomata, reduced number of flowers, disturbed stem and root elongation, impaired plant height, growth, development and yield, and reduced fresh and dry biomass $[7,39,50]$. 


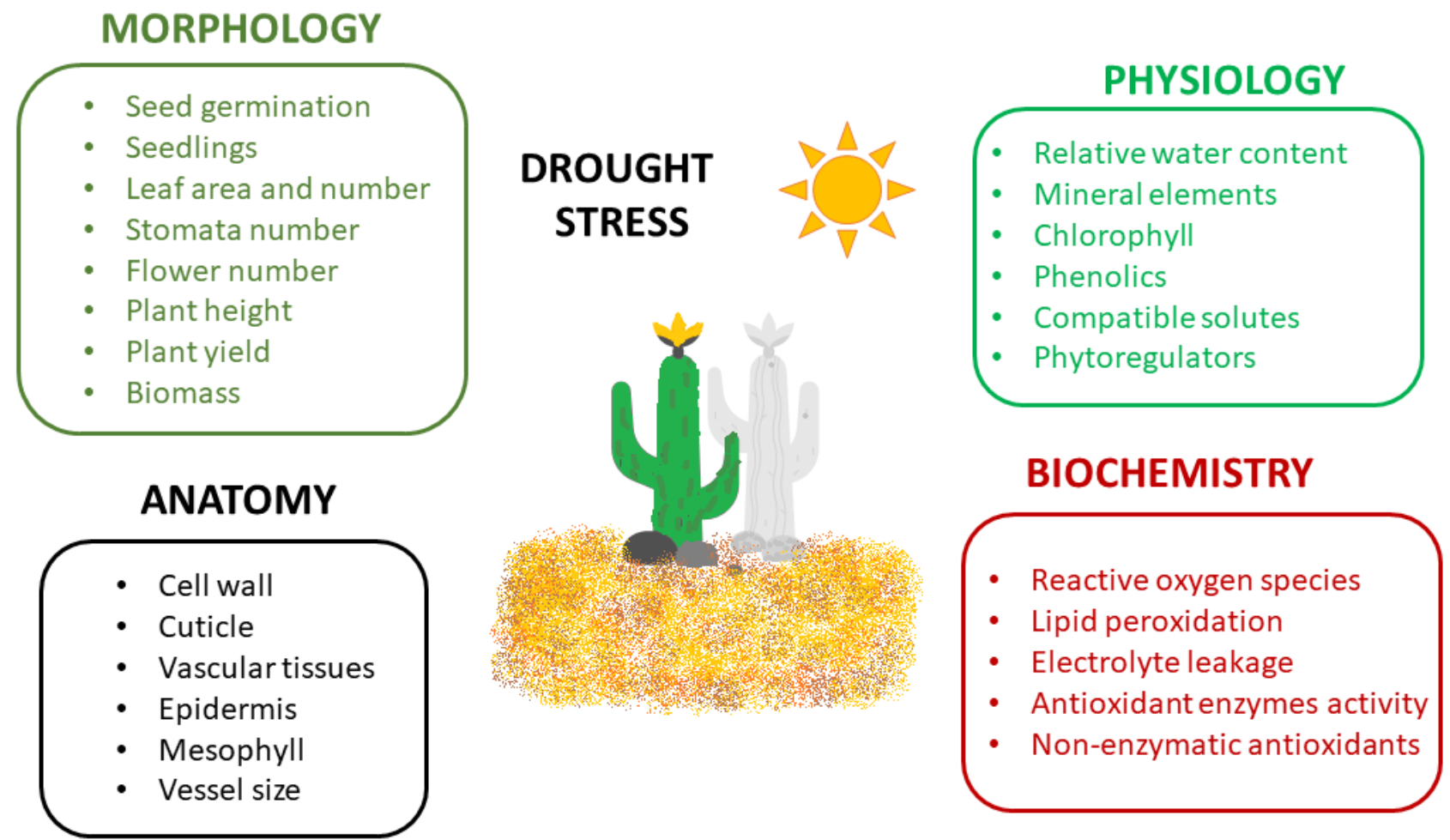

Figure 1. Some morphological, anatomical, physiological and biochemical plant responses to drought stress (modified on the basis of $[1,39,50])$.
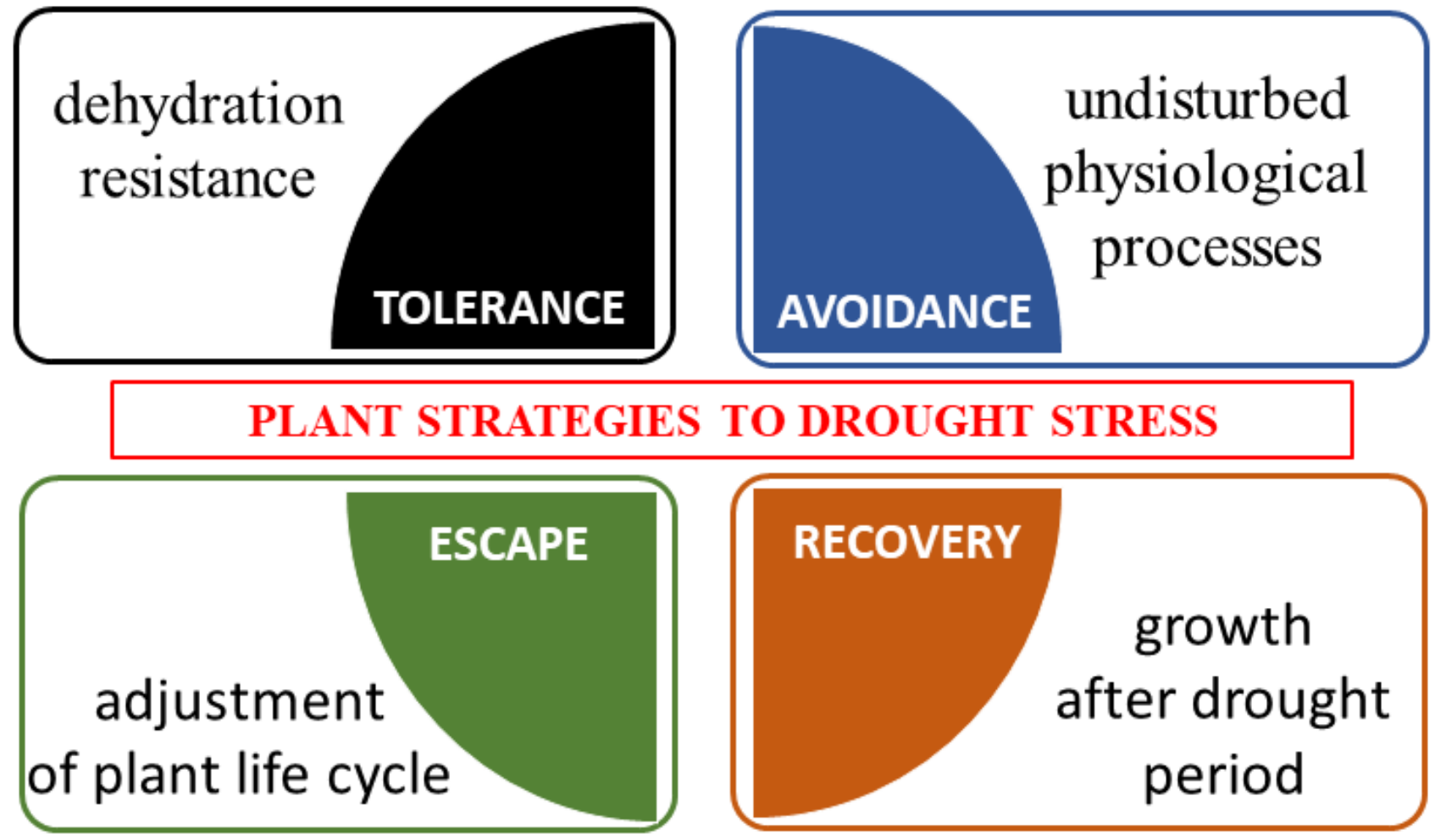

\section{PLANT STRATEGIES TO DROUGHT STRESS}

Figure 2. Response strategies to drought stress (modified on the basis of $[1,39,50,51]$ ). 
In order to adapt to the adverse environment, avoid drought and improve water availability, plants increase the root length and their number [54]. Drought significantly affects the plant's cell elongation and division, its growth and its development, which is mainly caused by the reduction in cellular differentiation, plant growth and yield [50]. The negative effect on the leaf area under the drought condition could be dependent on the reduction in the leaf number, size and longevity, combined with temperature, leaf turgor pressure and assimilation rate [55]. The reduction in plant height and shoot dry weight results in a lower quality of yield [54].

The morphological responses are most frequently combined with anatomical changes in plants exposed to drought, e.g., thickening of cell walls, increased cuticle layer on the leaf surface and improved development of vascular tissues [8,56]. Drought stress results in anatomical changes in the lower and upper epidermis, mesophyll tissue and vascular bundle diameter of leaves [57]. The negative anatomical effects on the leaves are based on a shortage of water supply from the soil, limitations in nutrients uptake, and reduction in photosynthetic rate. Plant hydraulic conductivity is modulated during drought stress leading to the disruption of water flow in the xylem vessels (embolism) or modifications in the vessel size and function [58]. Consequently, the reduced water flow from the root to the shoot causes stomatal closure and transpiration disruption [50].

Drought affects the physiological traits such as the leaf relative water content and water potential, stomatal conductance, transpiration and photosynthetic rates $[59,60]$. Reduced water content and water conductivity are responsible for the loss of turgidity and limited stomatal conductance resulting in restricted gaseous exchange (the rate of carbon assimilation) [8,61]. Furthermore, climatic conditions, e.g., higher temperature, drought and soil aeration reduce the movement of nutrients in the soil, their uptake by roots and transport in plant tissues [62].

Photosynthesis can be disrupted through the modulation of the electron transport chain and can increase the rate of biochemical reactions catalyzed by different enzymes. Above a certain temperature threshold, enzymes lose their function, influencing the plant tissue tolerance to drought $[1,63,64]$. Drought stress also affects the translocation of nutrients and the composition of minerals, antioxidants and proteins [39,52]. Under stress conditions, reactive oxygen species (ROS) are highly generated $[65,66]$ causing cell damage and plant necrosis [67]. Additionally, plant hormones and primary and secondary metabolites are modified [1]. Drought is the elicitor that can increase the content of secondary metabolites in plant tissues such as flavonoids, phenolics or more specific molecules, e.g., glycosides and alkaloids [68,69].

Crosstalk between drought and salinity stresses results in secondary stresses such as oxidative and osmotic ones [66]. Drought stress is a major agricultural problem worldwide and almost all of the main agricultural lands are affected by drought stress. The potential mechanisms of drought tolerance include: (1) production of phytohormones (such as indole-3-acetic acid (IAA), cytokinins and abscisic acid (ABA)) (2) synthesis of exopolysaccharides (3) activity of 1-aminocyclopropane-1-carboxylic acid (ACC) deaminase (4) induced systemic tolerance $[66,70]$.

\section{Mechanisms of Resistance in Plants}

Plants are capable of defending themselves against numerous stress factors, both biotic and abiotic ones, by activating very effective pathways of immunity (Figure 3). 


\section{Biotic and abiotic stress factors}
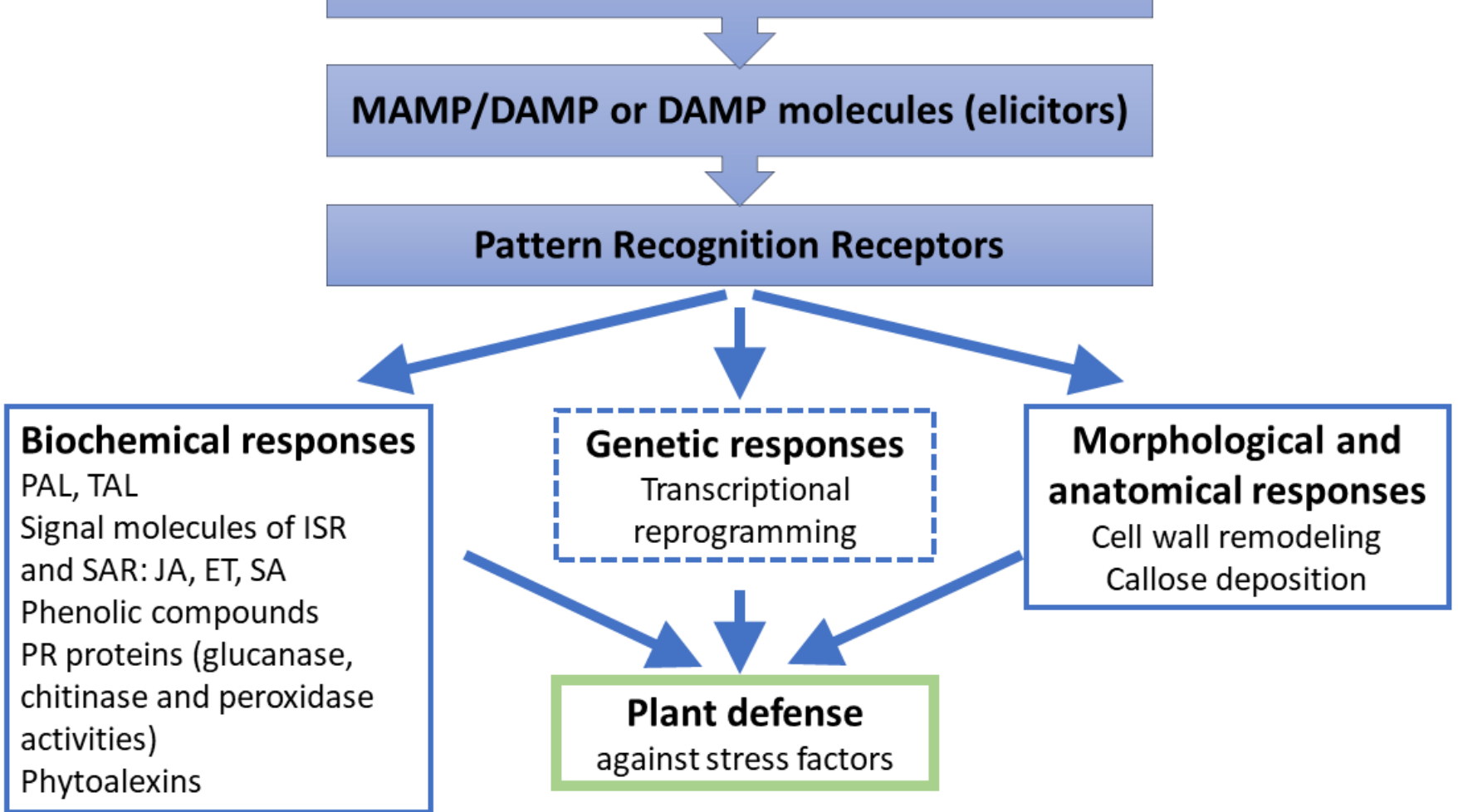

Figure 3. Immune response of plants against stress factors (modified on the basis of [71,72]); PAL—phenylalanine ammonialyase; TAL—tyrosine ammonia-lyase; ISR—induced systemic resistance, SAR—systemic acquired resistance; JA—jasmonic acid; ET—ethylene; SA—salicylic acid; PR proteins—pathogenesis related proteins.

The plant might acquire resistance against phytopathogenic infection due to the induction of plant defense responses driven by the very wide range of interactions with above- and below-ground microorganisms $[6,73,74]$. Several microbial species have displayed plant-priming phenomena. The priming process of plants is typically known in induced systemic resistance (ISR) and systemic acquired resistance (SAR), and microbeassociated molecular pattern (MAMP)-triggered immunity. ISR is mediated through the involvement of phytohormones, e.g., ethylene (ET) and jasmonic acid (JA), and the defense responses against phytopathogenic microorganisms are activated very quickly. SAR and MAMP-triggered immunity are induced as a first line, and unlike ISR, they utilize salicylic acid (SA) as signal substance of the plant resistance pathways $[6,73,74]$. The nonpathogenic microorganisms and various organic elicitors, mainly derived from microorganisms, act by inducing systemic acquired resistance (SAR) [75]. To elicit defense responses in plants, microorganisms secrete several molecules such as antibiotics (i.e., 2,4-diacetylphloroglucinol, phenazines synthesized by Pseudomonas species, and cyclic lipopeptides such as surfactin, synthesized by Bacillus strains), volatiles, quorum-sensing signals ( $\mathrm{N}$-acyl homoserine lactone of Gram-negative bacteria), proteins and small lowmolecular weight compounds [6]. Natural bioactive compounds of microbial, Protist or plant origins with the ability to protect plants against phytopathogens can have fungicidal effects (can kill pathogens) or fungistatic effects (can limit development of phytopathogens), as well as being able to induce plant defense reactions as elicitors [71,76]. Every factor (physical, chemical, biotic, abiotic and their mixture) that induces plant immunity or stimulates the defense mechanisms in a plant is called an elicitor and is defined depending on its origin and molecular structure [68]. MAMP-type molecules are exoelicitors of microbial origin. Pathogen-associated molecular pattern (PAMP)-type molecules are exoelicitors of pathogenic organism origin. Damage/danger-associated molecular pattern (DAMP)-type 
molecules are endoelicitors of plant origin released during phytopathogen infection or produced under various stresses, [77-79]. Receptor proteins in the plasma membrane-pattern recognition receptors (PRRs) recognize particular molecular patterns of MAMP/PAMP and DAMP molecules [80,81]. The priming or PAMP-triggered, (PTI)-type local immunity, which arises in the absence of virulent pathogens, is due to the rapid onset of intracellularsignaling-pathway activation leading to a very fast and effective defense responses in the plant [82].

In plants, a range of abiotic and biotic elicitors can strengthen tolerance to drought stress, including alginate-derived oligosaccharides, ketoconazole, 2-aminoethanol, ABA, brassinosteroids, and beneficial microorganisms such as Rhizobium strains, endo- and exomycorrhizal rhizospheric and endophytic nonpathogenic fungi. These elicitors reduced the content of monodehydroascorbate, prevented the accumulation of ROS, increased activities of antioxidant enzymes, and maintained fresh and dry weights, grain yield, and relative water content in a variety of plants in response to drought stress [83]. The term "induced systemic tolerance" (IST) has been suggested for PGPB-induced physical and chemical alterations that result in enhanced tolerance to abiotic stresses $[70,84,85]$.

\section{Bacteria Supporting Horticultural Crops}

The most promising solution for the future of modern horticulture seems to be the skillful use of biopreparations in the conventional crops and not limiting their use to a narrow range of ecological or organic farming crops. Biopreparations include at least three types of products: (1) biocontrol, or biological plant protection inhibiting directly (antagonism, competition) or indirectly (defense responses) the growth of phytopathogenic fungi or bacteria and other pests such as insects and nematodes, (2) biostimulation, positively affecting the plant development, increasing the plant biomass and yield, and (3) biofertilization, which provides nutrients and enhances plant nutrient uptake [6,29,71], (Table 1). The components of these biopreparations are very diverse, ranging from various inoculum types of microorganisms (either single or consortia of endophytic bacteria, fungi and Protista strains belonging to the plant growth-promoting group), through to metabolites, including phytohormonal and hormonelike substances or parts of microorganism cells, to various metabolites and structural compounds derived from microorganisms, Protista and plants often acting as the plant resistance elicitors [6,86]. Interestingly, the components of biopreparations are composed in such a way that, while performing biocontrol, biofertilizer and biostimulant functions [87-91], they reduce the impact of stresses caused by the numerous and dynamically changing environmental factors. Among these factors are rapid shifts in the temperature and humidity leading to the formation of drought, which reduces the availability of nutrients.

A very common approach is the isolation and application of active microorganisms to similar or the same plant and conditions, e.g., a Pseudomonas IACRBru1 strain isolated from Eruca versicaria (rucola) tissues improved Lactuca sativa (lettuce) biomass (up to 30\%) [92]. One of the critical steps for the successful application of microorganisms is their survival and development in the new environment. In drought-stressed soils, the highest efficiency of this inoculation could be achieved using drought-tolerant bacteria isolated from arid soils or drought-resistant plants [93-95]. Bacteria classified as Bacillus subtilis, Bacillus altitudinis, Brevibacillus laterosporus and Bacillus mojavensis were isolated from Cistanthe longiscapa, a plant native to Atacama Desert in Chile [94]. A consortium of these microorganisms, with various complementary properties such as phosphate solubilization, the ability to grow on $\mathrm{N}$-free culture, IAA, ACC-deaminase, and exopolysaccharide (EPS) synthesis, were applied onto tomato seeds, improving seedlings growth under drought stress. 
Table 1. Selected activities of beneficial bacteria under drought-stress conditions in horticultural plant species; $\mathrm{H}-$ higher level/content; L-lower level/content; GPX_glutathione peroxidase; CAT—catalase; Chl—chlorophyll; RWC—relative water content; Fv/Fm—quantum efficiency of photosystem II; SOD—superoxide dismutase; MDA—malondialdehyde.

\begin{tabular}{|c|c|c|c|}
\hline Bacteria & Changes in Plants & Plants & Ref. \\
\hline Bacillus pumilus & $\begin{array}{l}\text { - H total biomass (to } 34.9 \% \text { ) } \\
\text { - H antioxidant enzyme activities } \\
\text { - H flavonoids, polysaccharide and glycyrrhizic } \\
\text { acid contents }\end{array}$ & $\begin{array}{l}\text { Glycyrrhiza } \\
\text { uralensis }\end{array}$ & [96] \\
\hline Bacillus sp. & $\begin{array}{l}\text { - H roots and shoots fresh and dry weight } \\
\text { - H shoot length }\end{array}$ & $\begin{array}{l}\text { Cucumis } \\
\text { satious }\end{array}$ & [97] \\
\hline Azotobacter chroococcum & - L GPX activity (to $12.5 \%$ ) & Mentha pulegium & [98] \\
\hline $\begin{array}{l}\text { Pseudomonas putida KT2440 } \\
\text { (pUCP22:otsAB) }\end{array}$ & $\begin{array}{l}\text { - H trehalose [11-fold vs. P. putida KT2440 } \\
\text { (pUCP) without the gen] } \\
\text { - H fresh and dry weight } \\
\text { - H fully turgid weight } \\
\text { - H RWC }\end{array}$ & $\begin{array}{l}\text { Capsicum } \\
\text { annuum cv. Maor }\end{array}$ & [23] \\
\hline Azospirillum brasilense & $\begin{array}{l}\text { - L GPX activity (to } 14.7 \%) \\
\text { - H CAT activity (2.6-fold vs. control) }\end{array}$ & Mentha pulegium & [98] \\
\hline Variovorax paradoxus 5 C-2 & $\begin{array}{l}\text { - H shoot dry weight } \\
\text { - H net photosynthesis } \\
\text { - H relative Chl content } \\
\text { - L proline content }\end{array}$ & $\begin{array}{c}\text { Solanum } \\
\text { lycopresicum cv. Boludo F1 }\end{array}$ & [99] \\
\hline Rhodococcus sp. 4J2A2 & $\begin{array}{l}\text { xeroprotectant effect of trehalose } \\
\text { in preventing the biomolecules }\end{array}$ & $\begin{array}{l}\text { Solanum } \\
\text { esculentum cv. F144 }\end{array}$ & [23] \\
\hline $\begin{array}{l}\text { Azotobacter chroococcum } \\
\text { with } \\
\text { Azospirilum lipofrum }\end{array}$ & $\begin{array}{l}\text { - H fresh weight } \\
\text { - H root growth and length } \\
\text { - H total phenolics content in leaves } \\
\text { - H peroxidase activity }\end{array}$ & Juglans regia & [100] \\
\hline $\begin{array}{l}\text { Azotobacter chroococcum } \\
\text { with } \\
\text { Azospirillum brasilense }\end{array}$ & $\begin{array}{l}\text { - H RWC (from } 64.6 \% \text { to } 72.1 \% \text { ) } \\
\text { - H Fv / Fm (from } 0.56 \text { to } 0.75 \text { ) } \\
\text { - H SOD activity (from } 34.7 \% \text { to } 57.2 \% \text { ) } \\
\text { - L GPX activity (to } 26.9 \% \text { ) }\end{array}$ & Mentha pulegium & [98] \\
\hline $\begin{array}{l}\text { Microbacterium sp. 3J1 or } \\
\text { Arthrobacter koreensis 5J12A or } \\
\text { Arthrobacter piechaudii 366-5 }\end{array}$ & $\begin{array}{l}\text { - H fresh and dry weight } \\
\text { - H turgid weight } \\
\text { - H RWC } \\
\text { - H roots and stems length }\end{array}$ & $\begin{array}{l}\text { Capsicum } \\
\text { annuum cv. Maor }\end{array}$ & [23] \\
\hline $\begin{array}{l}\text { Bacillus cereus AR156 with } \\
\text { Bacillus subtilis SM21 with } \\
\quad \text { Serratia sp. XY21 }\end{array}$ & $\begin{array}{l}\text { - H proline content in leaves } \\
\text { - L MDA content in leaves } \\
\text { - L peroxidation in plasmalemma }\end{array}$ & $\begin{array}{l}\text { Cucumis } \\
\text { satious }\end{array}$ & [82] \\
\hline
\end{tabular}

It is worth emphasizing that among the most frequently mentioned PGPR strains of different genera, e.g., Pseudomonas, Bacillus, Klebsiella, Azotobacter, many Pseudomonas species show a very high diversity of traits stimulating plant growth. For this reason, many scientific laboratories are looking for such valuable isolates adapted to drought conditions [101-103] (Table 1). Pseudomonas putida, isolated by Kumar et al. [101], synthetized IAA, siderophore, ACC-deaminase, formed biofilm and solubilized phosphate. Pseudomonas aeruginosa strain, isolated from North East India, additionally showed HCN synthesis and endogenous osmolyte accumulation under the drought condition [103]. Sandhya et al. [102] also selected drought-tolerant Pseudomonas spp.: P. monteilli, P. putida, P. stutzeri, P. syringae from the rhizosphere of crop plants.

Niu et al. [93] isolated drought-tolerant plant growth-promoting bacteria from Setaria italica (foxtail millet) cultivated in arid soils. The bacterial strains identified in the roots and bulk soil (e.g., Pseudomonas fluorescens DR7 and DR11, Pseudomonas migulae DR35 and Enterobacter hormaechei DR16) synthetized ACC-deaminase under drought conditions. All 
the isolates produced EPS, but IAA activity was confirmed only in DR35 culture. Similarly, Pseudomonas sp. isolated from Californian soil exposed to frequent drought also showed significant production of EPS in response to desiccation [104].

Belonging to the PGPR family, Azospirillum spp. (Table 1) are a group of free-living soil bacteria mainly known for their ability to fix atmospheric nitrogen but also for releasing phytohormones, enhancing root growth, water and mineral uptake and plant resistance to drought stress $[105,106]$ (Table 1). As a microbial inoculant, Azospirillum spp. could be crucial to improve fruit-tree acclimatization when transferred to the post-vitro environment [106].

Mariotti et al. [105] revealed that Azospirillum baldaniorum cells and their metabolites promote Ocimum basilicum cv. Red Rubin (purple basil) growth under the water stress condition. This action was attributed to the synthesis and transport of phytohormones that promoted plant growth and conferred tolerance to the abiotic stress. The plant leaves treated with a relevantly high dose of the filtered culture supernatants of $A$. baldaniorum contained significantly higher concentration of chlorophyll $a$ and $b$, total chlorophyll, carotenoids, and anthocyanins. In the presence of these bacteria, in the tissues of purple basil, the concentration of stress-related phytohormones, ABA, JA and SA were higher. Azospirillum brasilence accompanied by Pseudomonas sp. and Bacillus lentus also caused a higher level of chlorophyll content in Ocimum basilicum grown under drought stress [107].

Moreover, at the end of the growing season, certain soil species, including soil-borne endophytic microorganisms promoting plant growth (e.g., including Bacillus, Clostridium and Sporolactobacillus genera), form endospores capable of remaining dormant in the soil. It is extremely important that in adverse environmental conditions (e.g., drought, very high or low temperature or higher amounts of incoming solar radiation) [1,108,109], when spores encounter the appropriate conditions (for example in the next growing season), they survive, germinate and the vegetative cells develop in the soil and are able to inhabit plants [109].

A mixture of three PGPR strains (Bacillus cereus AR156, Bacillus subtilis SM21, and Serratia sp. XY21) (Table 1) stimulated IST in drought stress in cucumber plants by maintaining the root recovery intensity, reducing plasmalemma peroxidation, stabilizing the osmotic potential, increasing photosynthesis efficiency and activities of SOD and cytoplasmic ascorbate peroxidase (APX) in the leaves, without involving the action of ACC deaminase to the lower plant ethylene levels [83].

\subsection{Bacillus Species in Drought Stress}

Among the features of the soil-aerobic, rod-shaped cells of Bacillus species (Table 1) contributing to the biocontrol mechanism is the synthesis and secretion of various antimicrobial peptides and very diverse antibiotics, enzymes, other proteins and organic compounds [110,111]. Inoculation of Cucumis sativus (cucumber) with Bacillus cereus and Bacillus subtilis strains along with Serratia sp. induced systemic tolerance to drought stress in plants by maintaining photosynthetic efficiency, root vigor, increasing proline content and enhanced SOD and CAT activities in the leaves [83]. In another experiment, to enhance Lycopersicon esculentum (tomato) drought tolerance, Bacillus cereus AR156 supernatant was applied. In the treated plants, chlorophyll $a$ and $b$ contents, as well as the activities of SOD, POD and CAT were increased markedly after culture supernatant application [112].

Plant small heat shock proteins (sHSPs) act as molecular chaperones that prevent irreversible aggregation of denatured proteins [85]. During drought stress, pepper plants inoculated with Bacillus licheniformis K11 exhibited enhanced transcription of Cadhn, VA, sHSP, and CaPR-10 genes [113,114]. In the study of Lim and Kim [113], the Capsicum annuum (pepper) seedlings were treated with a Bacillus licheniformis strain originated from Korean soil. Plants inoculated with drought-tolerant bacteria achieved higher shoot length and dry weight, and the analysis of gene expression in pepper roots indicated higher levels of expression of four genes related to drought and cold stresses. Bacillus sp. selected for high levels of cytokine synthesis was introduced into 12-day old L. sativa grown in dry soil. 
After 3 weeks of seedlings inoculation, the increased amount of cytokinin and higher fresh and dry weights of shoots were confirmed [115].

At the beginning of vegetative season, higher temperature induces microbial metabolism (including releasing of inorganic available $P$ to the soil solution by phosphate solubilizing microorganisms (PSM)) [116]. Gradually, the lack of adequate precipitation, insufficient soil moisture and high temperature decreased the soil microbial activity and the movement of nutrients in the soil [62]. Bacillus strains are commonly known to be great phosphate solubilizers [110]. Ying et al. [18] revealed high phosphatase activity of Bacillus megatherium and inorganic phosphate solubilization of Bacillus saryghattati strains under drought stress. Bacillus spp. (B. cultidtuctinus, B. subtilis, B. polymyxa and B. mojavensis) isolated from the Cistanthe longiscapa rhizosphere grown in the Atacama Desert (Chile) also exhibited phosphate-solubilizing activity [94].

It is worth noting that the activity of phosphate-solubilizing Bacillus strains support very energy-consuming processes of nitrogen fixation. Available $\mathrm{P}$ is a crucial ingredient of the energy source ATP. It can also replace conventional fertilization. An effective action on N and P uptake by the Vicia faba (faba bean) seeds and straws was confirmed after inoculation with the well-known phosphate-solubilizing bacterium Bacillus megatherium [117]. After inoculation of the apple trees cv. 'Topaz' with 'Mycostat' (containing Bacillus subtilis among strains promoting plant growth) the $P$ root content was the same as in the tissues treated with chemical NPK fertilizer [89]. In addition, when soil moisture declined, the limited diffusion rate of nutrients, particularly $\mathrm{P}$, from the soil matrix into the absorbing surface negatively affected nodulation and biological nitrogen fixation [118].

Plants with symptoms of potassium deficiency show accelerated wilting and lower yield, causing the loss of control of turgor-driven leaf movements [119]. Bacillus strains can secrete acidic metabolites (e.g., oxalic, fumaric, lemon, tartaric acids) that dissolve various minerals. Avakyan [120] demonstrated the ability to produce a thick EPS envelope by the strain Bacillus mucilaginosus. Secretion of the acidic metabolites by B. mucilaginosus cells creates a zone of strong acidification at the soil minerals' surface and allows the dissolution of mineral compounds. The polysaccharides secreted by these microorganisms additionally strongly adsorb $\mathrm{SiO}_{3}{ }^{-2}$ leaving bioavailable $\mathrm{K}$ cations for plants in the soil solution [121].

The plant root is involved in the perception and transduction of stress signals via phytoregulators such as ET [122]. The increased level of ET causes premature aging of fruits and vegetables; wilting of flowers and leafy vegetables and defoliation of the mature leaves. Additionally, higher concentrations of ET in the rhizosphere inhibits arbuscular mycorrhizal fungi colonization and the root nodulation of legumes. A Bacillus subtilis (LDR2) strain isolated from the rhizosphere of drought-stressed plants, synthetizes ACC deaminase-regulating ET concentration. In the experiment, a LDR2 strain revealed protective mechanisms against the low water availability in soil, and improved Trigonella plants' weights (by 56\%). Barnawall et al. [122] also demonstrated the enhanced nodulation and arbuscular mycorrhizal fungi colonization in the plants, which caused better nutrient uptake after inoculation of plants with B. subtilis.

In the face of climate change, certain future adaptations can be predicted by observing the functioning of organisms in extreme environments. In addition, in natural adverse ecosystems, except for the ability to form spores, microorganisms support plant growth and simultaneously provide an optimal environment for the development of plants tissues $[111,117,123]$, e.g., Bacillus mojavensis was isolated from the very extreme environment of the Mojave Desert in California [111]. All the strains belonging to this group are described as endophytic and antagonistic to fungi [124]. The endophytic microorganisms (including both obligate and facultative species) are microbial symbionts residing within plants, mostly influencing host physiology $[36,111]$.

The B. mojavensis strain isolated from the soybean plant rhizosphere was a very antagonistic strain, effectively controlling Rhizoctonia solani, a pathogenic fungus causing huge harvest losses of horticultural crops [125,126]. The presence of endophytic microorganisms with the biocontrol actions of soil-borne pathogens and the ability to stimulate the growth 
of cultivated plants from the early stages of its development seems to be a crucial solution for plants under unfavorable climate conditions. The inoculation of soybean seeds with the Bacillus mojavensis PB 35(R11) strain enhanced the growth of plant inoculated with $R$. solani (about 30\% higher plant fresh weight and over 100\% higher plant dry weight) [111]. Moreover, quantitative assays of the PB-35(R11) strain showed HCN, ammonia and siderophore production, as well as phosphate solubilization and chitinase activity. The treatment of seeds gives several advantages for the control of pathogenic fungi as a promising alternative to the use of synthetic pesticides. The endophytic Bacillus inoculants are also known for controlling Fusarium species, especially Fusarium verticillioides [124,127].

\subsection{Actinomycetes Species in Drought Stress}

A more advantageous strategy is the selection of microorganisms adapted to functioning in the conditions of temporary lack of water, drought, or rapid changes in temperature, because the metabolically active forms of microorganisms may support the growth of sensitive horticultural crops. Actinomycetes are Gram-positive, mostly aerobic, saprotrophic bacteria of diverse phenotypes (from cocci to highly differentiated mycelia).

Tangles of filaments grow similarly to filamentous fungi. This pseudomycelial growth (surface, plunge or air) provides penetration of a larger soil volume and into pores of soil, easing access to valuable minerals and simultaneously making them available to plants [128].

The main place of Actinomycetes occurrence is the soil (warm and humid or dry), but they are also identified in desert sands, on leaves and in plant tissues [129]. Reproduction of these bacteria occurs by fragmentation of pseudomycelium and spore formation. This group of microorganisms are mostly chemoorganotrophs with the ability to break down difficult decomposing substrates, e.g., cellulose, chitin, steroids, higher fatty acids or aromatic compounds. These activities allow them to survive and outcompete the native microflora in various ecological niches [130]. Lawlor et al. [131] revealed a higher number of Actinomycetes colony forming units (CFU) (about $10^{6}$ to $10^{7} \mathrm{~g}^{-1}$ of dry weight of soil) than CFU of fungi ( $10^{4}$ to $10^{5} \mathrm{~g}^{-1}$ of dry weight of soil).

Actinomycetes are known to be producers of bioactive compounds (antibacterial, antifungal), exhibiting great potential in promoting plant growth [129]. Sousa et al. [3] investigated that the Streptomyces strains produce siderophores, phytohormones (IAA), and solubilizing phosphate compounds, and exhibit chitinase, xylanase, cellulase, amylase and lipase activities. Additionally, the number of plant growth-promoting Actinobacteria is 1.3 times higher than that of the other bacteria [132].

Khamna et al. [133] identified about 30 Streptomyces isolates in Thai soil samples collected from the rhizospheres of plants such as Curcuma magga, Zingiber officinale (ginger), Ocimum sanctum (holy basil), and Cumbopogon citratus (lemongrass). After 3-day incubation, the Streptomyces CMU-H009 strain synthetized the highest concentration of IAA (about $144 \mu \mathrm{g} \cdot \mathrm{mL}^{-1}$ ) and its culture filtrates stimulated Vigna unguiculata (cowpea) seed germination. El-Tarabily [134] isolated over 60 Streptomyces spp. strains from a tomato rhizosphere in the United Arab Emirates and some of them revealed ACC-deaminase and IAA synthesis. The most efficient Streptomyces filipinensis 15, Streptomyces atrovirens 26 and Streptomyces albovinaceus 41 strains increased Lycopersicon esculentum (tomato) root and shoot length and dry weight. A higher level of endogenous IAA in the roots and shoots in these plants was also confirmed. Actinomycetes exhibited great potential in promoting rice, sorghum [135], tomato [134], maize [136] and soybean seedling growth [137].

It is worth emphasizing that some Actinomycetes (e.g., Frankia sp.) function in a symbiosis with higher plants, fixing nitrogen, while the plant provides the bacteria with sugars and minerals [136]. Such a favorable relationship has been observed in soybeans, peas, Elaeagnus umbellata and Eleangus angustifolia (Russian olive) [138].

A variety of activities improving plant development have been indicated in the Acitnomycetes species, and their efficiency obtained by adapting to adverse climatic conditions enables them to receive commercial products containing PGPA (plant growth-promoting 
actinobacteria), such as Streptomyces lydicus strains. Acitnomycetes species (Streptomyces kasugaensis, Streptomyces griseus and Streptomyces cacoi var. asoensis) producing antibacterial and antifungal bioactive compounds are components of biocontrol products applied against plant pathogens [129]. Actinomycetes synthesize enzymes such as lysozyme, glucanases, peptide-peptide hydrolases, mannanase and chitinase, which are involved in the lysis of the cell walls of other microorganisms [128]. El Tarabily et al. [134] investigated the promotion and biological control of seedlings and the mature plants of $C$. sativus using endophytic Actinomycetes (Actinoplanes campanulatus, Micromonospora chalcea and Streptomyces spiralis). Pythium aphanidermatum (oospore-producing soil-borne pathogen) causes seedling and root diseases of cucumber, causing damage to horticultural crops. This experiment proved that Actinomycetes colonize the roots of inoculated plants, promoted their growth and reduced the impact of $P$. aphanidermatum. Furthermore, El Tarabily et al. [134] compared the impact of Actinomycetes with chemical fungicide (metalaxyl) and demonstrated the possibility of replacing fungicide with plant inoculation with endophytic Actinomycetes.

\section{Plant Growth-Promoting Fungi in Horticultural Crops}

Among microorganisms, fungi can be much more drought-tolerant than bacteria [139] due to a number of mechanisms to overcome drought stress, including osmolytes, thick cell walls, and melanin [140]. Yeast cells are encased in a protective cell wall and cells of filamentous fungi can be connected, allowing water and solutes to flow between them. The filamentous fungi produce extremally long hypha, enabling the extraction of water from remote sites in the soil. Fungal abundance in the soil can increase under drought. They can remain active and even grow under extremely dry conditions. Their resistance to drought allows them to conduct the basic processes of decomposition of polymer compounds and the circulation of C and N [139]. Fungi, bacteria, seaweeds and plants are able to accumulate osmoprotectants, for instance amino acids (e.g., proline, glutamate), carbohydrates (trehalose), sugar alcohols (inositol, mannitol), quaternary ammonium compounds (glycine betaine) and tertiary sulphonium compounds (e.g., dimethylsulphoniopropionate) [141].

Plants use various mechanisms to protect against water deficiency, but some of them are associated with the presence of fungi with special activities (Table 2). Eukaryotic plant endophytes belong mainly to the fungi kingdom $[142,143]$ and the most numerous among these endophytes are Glomeromycota (40\%), Ascomycota (31\%), Basidiomycota (20\%), Zygomycota $(0.1 \%)$ and unidentified phylla ( $8 \%)$. The Glomeromycota phyllum includes only arbuscular mycorrhizal fungi (AMF), whose species protect against phytopathogens, promote plant growth and counteract diverse stresses (mainly drought and salinity) by activating stress responsive/induced genes in plants. AMF are able to create a symbiosis with many horticultural plants belonging to various families, e.g., Alliaceae, Apiaceae, Asteraceae, Fabaceae, Solanaceae, Rosaceae, and Oleaceae [144-146]. Arbuscular mycorrhiza (AM) is the endomycorrhizal symbiotic association improving the nutrient uptake and growth of plants which may protect the host plants from pathogens and the harmful effects of drought $[144,146,147]$. Interactions with AMF, through an extensive network of hyphae, supply the plant with water from distant places. Studies have shown that AMF mainly use plant-derived carbohydrates in symbiosis with plants, and the plant receives access to the bioavailable minerals absorbed by the fungus from the soil (especially phosphorus). Moreover, the hyphae of fungal strains can uptake phosphorus and ammonium ions much more efficiently than the plant roots [148].

Moreover, fungi may influence the hormonal balance of plants by producing phytohormones (auxins, gibberellins) and through tolerance and resistance pathways, which protect the plant against biotic and abiotic factors. Both ectomycorrhizal (EMF, e.g., Laccaria spp.)and endomycorrhizal-AMF fungi (e.g., belonging to the Glomus, Rhizophagus, Funneliformis genera) are capable of inducing the ISR resistance pathways involving JA as a signaling substance, or SAR, in which signaling occurs thanks to the SA molecules [149]. The production of auxins by the fungal endophytes increases the growth of plants under stress [150]. After the plant under stress is colonized by endophytes, stress-induced levels of ABA and some 
genes' expressions (e.g., zeaxanthin epoxidase, 9-cis-epoxycarotenoid dioxygenase 3 and ABA aldehyde oxidase 3) were decreased. Similar effects were achieved in the promotion of plant growth and yield under stress conditions, after exogenous phytohormone application such as gibberellic acid [151]. Sometimes endophytes do not have positive effects on plant growth during drought, but they improve plant recovery after water shortage [152].

The presence of some fungal endophytes (e.g., in the Nicotiana benthamiana seedlings) increased the leaf area, chlorophyll content, photosynthetic rate, antioxidative enzyme activities, accumulation of osmoprotectants (sugar, protein and proline) and enhanced expression of drought-related genes $[153,154]$. On the other hand, in drought conditions, the relative water content in leaves and soluble protein content in the tissues of Cinnamomum migao did not change after 120-day inoculation with Glomus lamellosum [155] (Table 2). In drought-suffering plants, after endophyte inoculation, a lower level of biomolecule degradation was observed as a consequence of the reduced level of ROS production, e.g., in tomato [156]. In the face of drought stress, inoculation with Piriformospora indica (Table 2) mobilized activities of peroxidase (POX), catalase (CAT) and superoxide dismutase (SOD) in the leaves [157]. The endophytic fungal strains of Ampelomyces sp. isolated from soil exposed to drought enhanced drought tolerance in tomato [143,158]. Inoculation of tomato seedlings with Alternaria spp. strains under drought conditions resulted in the maintenance of the photosynthetic efficiency and effective reduction of ROS accumulation [156].

Table 2. Selected activities of beneficial fungi under drought stress conditions in horticultural plant species; $\mathrm{H}-$ higher level/content; L—lower level/content; Chl—chlorophyll; CAT—catalase; SOD—superoxide dismutase; MDA—malondialdehyde.

\begin{tabular}{|c|c|c|c|}
\hline Fungi & Changes in Plants & Plants & Ref. \\
\hline Glomus intraradices & $\begin{array}{l}\text { - H content of } \mathrm{N} \text { in roots and shoots } \\
\text { - H flower and fruit production } \\
\text { - H fruit yield } \\
\text { - H dry root mass }\end{array}$ & $\begin{array}{l}\text { Lycopersicum } \\
\text { esculentum }\end{array}$ & [159] \\
\hline Glomus mosesseae & $\begin{array}{l}\text { - slow down the reduction of } \mathrm{Chl} a+b \\
\text { - inhibit the decomposition of carotenoids }\end{array}$ & $\begin{array}{l}\text { Fragaria } x \\
\text { ananassa }\end{array}$ & [32] \\
\hline Glomus etunicatum & $\begin{array}{l}\text { - H fresh weight } \\
\text { - H number of leaves } \\
\text { - H content of N, P, Zn in leaves }\end{array}$ & Juglans regia & [100] \\
\hline Ampelomyces sp. & $\begin{array}{l}\text { - H dry weight of root and shoot } \\
\text { - H fruit weight } \\
\text { - H stress tolerance }\end{array}$ & $\begin{array}{c}\text { Solanum } \\
\text { lycopersicum } \\
\text { var. Better Boy }\end{array}$ & [158] \\
\hline Phoma spp. & $\begin{array}{l}\text { - H proline content, CAT and SOD activities } \\
\text { - H chlorophyll content } \\
\text { - H MDA content } \\
\text { - H water content in leaves }\end{array}$ & $\begin{array}{l}\text { Pinus } \\
\text { tablaeformis }\end{array}$ & [160] \\
\hline Piriformospora indica & $\begin{array}{l}\text { - H root and shoot growth } \\
\text { - H lateral root development } \\
\text { - H peroxidase, CAT and SOD activities in leaves }\end{array}$ & Brassica rapa subsp. pekinensis & [157] \\
\hline Trichodermaharzianum & $\begin{array}{l}\text { - H fresh and dry weight of roots } \\
\text { - H osmolyte concentration }\end{array}$ & Theobroma cacao & [160] \\
\hline $\begin{array}{l}\text { Glomus mossae } \\
\text { with } \\
\text { Glomus etunicatum }\end{array}$ & $\begin{array}{l}\text { - H height } \\
\text { - H content of N, P, Zn in leaves } \\
\text { - L leaves abscission }\end{array}$ & Juglans regia & [100] \\
\hline $\begin{array}{l}\text { Glomus lamellosum } \\
\text { or } \\
\text { Glomus etunicatum }\end{array}$ & $\begin{array}{l}\text { - H fresh and dry weight } \\
\text { - H stem fresh weight } \\
\text { - H water content in leaves } \\
\text { - L MDA content } \\
\text { - H CAT activity }\end{array}$ & Cinnamomum migao & [155] \\
\hline
\end{tabular}


Table 2. Cont.

\begin{tabular}{|c|c|c|c|}
\hline Fungi & Changes in Plants & Plants & Ref. \\
\hline $\begin{array}{l}\text { Glomus mosseae or } \\
\text { G. versiforme or } \\
\text { G. diaphanum }\end{array}$ & $\begin{array}{l}\text { - H enzyme activity in soil } \\
\text { - L CAT activity in soil } \\
\text { - H hyphal density }\end{array}$ & $\begin{array}{l}\text { Poncirus } \\
\text { trifoliata }\end{array}$ & [161] \\
\hline $\begin{array}{l}\text { Chaetomium globosum } \\
\text { or } \\
\text { Penicillium resedanum }\end{array}$ & $\begin{array}{l}\text { - H shoot dry weight } \\
\text { - H shoot length } \\
\text { - H photosynthesis rate }\end{array}$ & Capsicum annum & [151] \\
\hline $\begin{array}{c}\text { Alternaria } \mathrm{sp} . \\
\text { or } \\
\text { Trichoderma harzianum }\end{array}$ & - H root and shoot dry weight & $\begin{array}{c}\text { Solanum } \\
\text { lycopersicum } \\
\text { var. Rutger }\end{array}$ & [156] \\
\hline
\end{tabular}

The presence of beneficial fungal strains in soil and plants might specifically induce resistance by releasing elicitors belonging to fungal-derived compounds, e.g.: chitin, chitosan, ergosterol, $\beta$-glucans [151]. Moreover, among the pathogenic microorganisms, the filamentous fungi are responsible for horticultural crop diseases. It should be also noted that fungal endophytes belonging to PGP (e.g., Colletotrichum sp., Alternaria sp., Fusarium sp. and Aspergillus sp.) induce plant resistance and increase plant tolerance to drought, but may also produce mycotoxins in plants [162]. To increase specificity and enhancement of the induction, elicitors can be derived from the nonpathogenic fungi belonging to the same genus as the pathogenic strains causing plant diseases, e.g., Fusarium or Trichoderma [152]. In grapevine with black-foot disease (Dactylonectria and Cylindrocarpon genera), the relative abundance of the potential biocontrol agent Trichoderma in the root endosphere, rhizosphere, and bulk soil under drought stress (25\% irrigation regime) was significantly lower than in control conditions (50-100\% irrigation regime) [163]. Moreover, enrichment in AMF Funneliformis during drought was observed.

Recent and particularly promising studies have focused on the determination of the effectiveness and reliability of a mixture of bacterial and fungal strains (Table 3).

Table 3. Selected activities of beneficial consortia (bacteria with fungi) under drought stress conditions in horticultural plant species; H—higher level/content; L—lower level/content; CAT—catalase; APX—ascorbate peroxidase; Chl—chlorophyll.

\begin{tabular}{|c|c|c|c|}
\hline Bacteria with Fungi & Changes in Plants & Plants & Ref. \\
\hline $\begin{array}{c}\text { Pseudomonas fluorescence } \\
\text { with } \\
\text { Trichoderma harzianum }\end{array}$ & $\begin{array}{l}\text { - H growth parameters } \\
\text { - H seedling emergency } \\
\text { - H root and shoot length } \\
\text { - H CAT and APX activities }\end{array}$ & Cuminum суminum & [164] \\
\hline $\begin{array}{l}\text { Variovorax paradoxus } 5 C-2 \\
\text { with } \\
\text { Rhizophorus irregularis MULC }\end{array}$ & $\begin{array}{l}\text { - H shoot dry weight } \\
\text { - H net photosynthesis } \\
\text { - no change: relative Chl content vs. control } \\
\text { - H oxidative damage } \\
\text { - L proline content }\end{array}$ & $\begin{array}{c}\text { Solanum } \\
\text { lycopersicum cv. Boludo F1 }\end{array}$ & [99] \\
\hline
\end{tabular}

\section{Conclusions}

The EGD emphasizes sustainable food production by the crucial reduction in the use of pesticides, biocides and chemical mineral fertilizers and increase of organic (ecological) production. Consequently, in many European countries, continuous research has been carried out on natural biopreparations (biocontroling, biofertilizers) containing selected microorganisms with different activities, and/or their metabolites.

The key problems of using biopreparations containing various microorganisms include limiting the possibility of introducing the microbial inoculum to the appropriate conditions and the low repeatability of their activities. This might be due to drought stress during the vegetative period in comparison to microorganisms tested in the optimal conditions. 
The resistance of plants that interact with microorganisms in drought conditions is enhanced because it is induced by both abiotic (stress factor) and the biotic (microorganism) elicitors. In drought conditions, many cultivated horticultural plants use their own numerous mechanisms (morphological, physiological, anatomical, biochemical or molecular) to counteract the negative effects and are supported by endophytes that constantly inhabit them, and rhizospheric microorganisms existing in the vicinity of roots.

The use of preparations containing fungal strains, which are more tolerant to drought than bacteria, provides many tolerance mechanisms, and their abundance increases in water-limiting conditions. Fungi, through their specific growth and traits, allow intensive soil exploration, water extraction and penetration of plant tissues influencing the plant and might be more effective compared to bacteria with the same activity.

Studies on the influence of drought stress on horticultural plants have indicated that the application of various microorganisms allows efficient protection of plants, despite our restricted knowledge about these mechanisms of action. Due to such a high variability of the environment, biopreparations should be multicomponent in order to achieve appropriate levels of microorganism cooperation and the final desired effect. The combination of fungal and bacterial strains into one preparation gives even better effectiveness and reliability, allowing us to consider higher crop-specificity, and seems to be particularly promising.

Author Contributions: Conceptualization, A.H.; E.O. and J.J.-Ś.; writing—original draft preparation, E.O.; A.H.; E.R. and J.J.Ś.; writing—review and editing, A.H.; E.O.; E.R. and M.S.; visualization, A.H.; E.O.; E.R. and M.S. All authors have read and agreed to the published version of the manuscript.

Funding: This research received no external funding.

Institutional Review Board Statement: Not applicable.

Informed Consent Statement: Not applicable.

Conflicts of Interest: The authors declare no conflict of interest.

\section{References}

1. Moretti, C.L.; Mattos, L.M.; Calbo, A.G.; Sargent, S.A. Climate changes and potential impacts on postharvest quality of fruit and vegetable crops: A review. Food Res. Int. 2010, 43, 1824-1832. [CrossRef]

2. Hamid, B.; Zaman, M.; Farooq, S.; Fatima, S.; Sayyed, R.Z.; Baba, Z.A.; Sheikh, T.A.; Reddy, M.S.; El Enshasy, H.; Gafur, A.; et al. Bacterial plant biostimulants: A sustainable way towards improving growth, productivity, and health of crops. Sustainability 2021, 13, 2856. [CrossRef]

3. Sousa, C.S.; Soares, A.C.F.; Garrido, M.S. Characterization of Streptomycetes with potential to promote plant growth and biocontrol. Sci. Agric. 2008, 65, 50-55. [CrossRef]

4. Shah, A.; Nazari, M.; Antar, M.; Msimbira, L.A.; Naamala, J.; Lyu, D.; Rabileh, M.; Zajonc, J.; Smith, D.L. PGPR in agriculture: A sustainable approach to increasing climate change resilience. Front. Sustain. Food Syst. 2021, 5, 1-22. [CrossRef]

5. International Society for Horticultural Science. Available online: https://www.ishs.org/defining-horticulture (accessed on 27 September 2021).

6. Vishwakarma, K.; Kumar, N.; Shandilya, C.; Mohapatra, S.; Bhayana, S.; Varma, A. Revisiting plant-microbe interactions and microbial consortia application for enhancing sustainable agriculture: A review. Front. Microbiol. 2020, 11, 560406. [CrossRef]

7. Khan, N.; Ali, S.; Shahid, M.A.; Mustafa, A.; Sayyed, R.Z.; Curá, J.A. Insights into the interactions among roots, rhizosphere, and rhizobacteria for improving plant growth and tolerance to abiotic stresses: A review. Cells 2021, 10, 1551. [CrossRef]

8. Ullah, A.; Nisar, M.; Ali, H.; Hazrat, A.; Hayat, K.; Keerio, A.A.; Ihsan, M.; Laiq, M.; Ullah, S.; Fahad, S.; et al. Drought tolerance improvement in plants: An endophytic bacterial approach. Appl. Microbiol. Biotechnol. 2019, 103, 7385-7397. [CrossRef]

9. Yan, L.; Zhu, J.; Zhao, X.; Shi, J.; Jiang, C.; Shao, D. Beneficial effects of endophytic fungi colonization on plants. Appl. Microbiol. Biotechnol. 2019, 103, 3327-3340. [CrossRef]

10. Cheng, Y.T.; Zhang, L.; He, S.Y. Plant-microbe interactions facing environmental challenge. Cell Host Microbe 2019, 26, 183-192. [CrossRef]

11. Kavadia, A.; Omirou, M.; Fasoula, D.; Ioannides, I.M. The importance of microbial inoculants in a climate-changing agriculture in Eastern Mediterranean region. Atmosphere 2020, 11, 1136. [CrossRef]

12. Malik, A.; Mor, V.S.; Tokas, J.; Punia, H.; Malik, S.; Malik, K.; Sangwan, S.; Tomar, S.; Singh, P.; Singh, N.; et al. Biostimulant-treated seedlings under sustainable agriculture: A global perspective facing climate change. Agronomy 2021, 11, 14. [CrossRef]

13. Porter, S.S.; Bantay, R.; Friel, C.A.; Garoutte, A.; Gdanetz, K.; Ibarreta, K.; Moore, B.M.; Shetty, P.; Siler, E.; Friesen, M.L. Beneficial microbes ameliorate abiotic and biotic sources of stress on plants. Funct. Ecol. 2020, 34, 2075-2086. [CrossRef] 
14. Fincheira, P.; Quiroz, A.; Tortella, G.; Diez, M.C.; Rubilar, O. Current advances in plant-microbe communication via volatile organic compounds as an innovative strategy to improve plant growth. Microbiol. Res. 2021, 247, 126726. [CrossRef] [PubMed]

15. Hanaka, A.; Ozimek, E.; Majewska, M.; Rysiak, A.; Jaroszuk-Ściseł, J. Physiological diversity of Spitsbergen soil microbial communities suggests their potential as plant growth-promoting bacteria. Int. J. Mol. Sci. 2019, 20, 1207. [CrossRef] [PubMed]

16. Hanaka, A.; Nowak, A.; Plak, A.; Dresler, S.; Ozimek, E.; Jaroszuk-Ściseł, J.; Wójciak-Kosior, M.; Sowa, I. Bacterial isolate inhabiting Spitsbergen soil modifies the physiological response of Phaseolus coccineus in control conditions and under exogenous application of methyl jasmonate and copper excess. Int. J. Mol. Sci. 2019, 20, 1909. [CrossRef] [PubMed]

17. Compant, S.; Van Der Heijden, M.G.A.; Sessitsch, A. Climate change effects on beneficial plant-microorganism interactions. FEMS Microbiol. Ecol. 2010, 73, 197-214. [CrossRef]

18. Ma, Y.; Vosátka, M.; Freitas, H. Editorial: Beneficial microbes alleviate climatic stresses in plants. Front. Plant Sci. 2019, 10, 595. [CrossRef] [PubMed]

19. Vimal, S.R.; Singh, J.S.; Arora, N.K.; Singh, S. Soil-plant-microbe interactions in stressed agriculture management: A review. Pedosphere 2017, 27, 177-192. [CrossRef]

20. Gupta, S.; Seth, R.; Sharma, A. Plant Growth-Promoting Rhizobacteria Play a Role as Phytostimulators for Sustainable Agriculture; Choudhary, D., Varma, A., Tuteja, N., Eds.; Springer: Singapore, 2016.

21. Ma, Y.; Oliveira, R.S.; Freitas, H.; Zhang, C. Biochemical and molecular mechanisms of plant-microbe-metal interactions: Relevance for phytoremediation. Front. Plant Sci. 2016, 7, 918. [CrossRef]

22. Pirttilä, A.M.; Tabas, H.M.P.; Baruah, N.; Koskimäki, J.J. Biofertilizers and biocontrol agents for agriculture: How to identify and develop new potent microbial strains and traits. Microorganisms 2021, 9, 817. [CrossRef]

23. Vílchez, J.I.; García-Fontana, C.; Román-Naranjo, D.; González-López, J.; Manzanera, M. Plant drought tolerance enhancement by trehalose production of desiccation-tolerant microorganisms. Front. Microbiol. 2016, 7, 1577. [CrossRef]

24. Finkel, O.M.; Castrillo, G.; Herrera Paredes, S.; Salas González, I.; Dangl, J.L. Understanding and exploiting plant beneficial microbes. Curr. Opin. Plant Biol. 2017, 38, 155-163. [CrossRef] [PubMed]

25. Meena, K.K.; Sorty, A.M.; Bitla, U.M.; Choudhary, K.; Gupta, P.; Pareek, A.; Singh, D.P.; Prabha, R.; Sahu, P.K.; Gupta, V.K.; et al. Abiotic stress responses and microbe-mediated mitigation in plants: The omics strategies. Front. Plant Sci. 2017, 8, 172. [CrossRef] [PubMed]

26. Anjum, S.A.; Ashraf, U.; Zohaib, A.; Tanveer, M.; Naeem, M.; Ali, I.; Tabassum, T.; Nazir, U. Growth and developmental responses of crop plants under drought stress: A review. Zemdirb. Agric. 2017, 104, 267-276. [CrossRef]

27. Sharma, M.; Sudheer, S.; Usmani, Z.; Rani, R.; Gupta, P. Deciphering the omics of plant-microbe interaction: Perspectives and new insights. Curr. Genom. 2020, 21, 343-362. [CrossRef]

28. Vasseur-Coronado, M.; du Boulois, H.D.; Pertot, I.; Puopolo, G. Selection of plant growth promoting rhizobacteria sharing suitable features to be commercially developed as biostimulant products. Microbiol. Res. 2021, 245, 1-10. [CrossRef]

29. Pylak, M.; Oszust, K.; Frac, M. Review report on the role of bioproducts, biopreparations, biostimulants and microbial inoculants in organic production of fruit. Rev. Environ. Sci. Biotechnol. 2019, 18, 597-616. [CrossRef]

30. Kränzlein, M.; Geilfus, C.-M.; Franzisky, B.L.; Zhang, X.; Wimmer, M.A.; Zörb, C. Physiological responses of contrasting maize (Zea mays L.) hybrids to repeated drought. J. Plant Growth Regul. 2021. [CrossRef]

31. Jamil, M.; Ahamd, M.; Anwar, F.; Zahir, Z.A.; Kharal, M.A.; Nazli, F. Inducing drought tolerance in wheat through combined use of L-tryptophan and Pseudomonas fluorescens. Pak. J. Agric. Sci. 2018, 55, 331-337. [CrossRef]

32. Yin, B.; Wang, Y.; Liu, P.; Hu, J.; Zhen, W. Effects of vesicular-arbuscular mycorrhiza on the protective system in strawberry leaves under drought stress. Front. Agric. China 2010, 4, 165-169. [CrossRef]

33. Hone, H.; Mann, R.; Yang, G.; Kaur, J.; Tannenbaum, I.; Li, T.; Spangenberg, G.; Sawbridge, T. Profiling, isolation and characterisation of beneficial microbes from the seed microbiomes of drought tolerant wheat. Sci. Rep. 2021, 11, 11916. [CrossRef]

34. Zapata, T.; Galindo, D.M.; Corrales-Ducuara, A.R.; Ocampo-Ibáñez, I.D. The diversity of culture-dependent gram-negative Rhizobacteria associated with manihot esculenta crantz plants subjected to water-deficit stress. Diversity 2021, 13, 366. [CrossRef]

35. Mustafa, S.; Kabir, S.; Shabbir, U.; Batool, R. Plant growth promoting rhizobacteria in sustainable agriculture: From theoretical to pragmatic approach. Symbiosis 2019, 78, 115-123. [CrossRef]

36. Ozimek, E.; Hanaka, A. Mortierella species as the plant growth-promoting fungi present in the agricultural soils. Agriculture 2021, 11, 7. [CrossRef]

37. IPCC Climate Change. The Physical Science Basis 2021; IPCC Climate Change: Geneva, Switzerland, 2021.

38. Lelieveld, J.; Hadjinicolaou, P.; Kostopoulou, E.; Chenoweth, J.; El Maayar, M.; Giannakopoulos, C.; Hannides, C.; Lange, M.A.; Tanarhte, M.; Tyrlis, E.; et al. Climate change and impacts in the Eastern Mediterranean and the Middle East. Clim. Chang. 2012, 114, 667-687. [CrossRef] [PubMed]

39. Ilyas, M.; Nisar, M.; Khan, N.; Hazrat, A.; Khan, A.H.; Hayat, K.; Fahad, S.; Khan, A.; Ullah, A. Drought tolerance strategies in plants: A mechanistic approach. J. Plant Growth Regul. 2021, 40, 926-944. [CrossRef]

40. Hanaka, A.; Plak, A.; Zagórski, P.; Ozimek, E.; Rysiak, A.; Majewska, M.; Jaroszuk-Ściseł, J. Relationships between the properties of Spitsbergen soil, number and biodiversity of rhizosphere microorganisms, and heavy metal concentration in selected plant species. Plant Soil 2019, 436, 49-69. [CrossRef]

41. Mędrek, K.; Gluza, A.; Siwek, K.; Zagórski, P. The meteorological conditions on the Calypsobyen in summer 2014 on the background of multiyear 1986-2011. Probl. Klim. Polar. 2014, 24, 37-50. (In Polish) 
42. Franczak, Ł.; Kociuba, W.; Gajek, G. Runoff variability in the Scott River (SW Spitsbergen) in summer seasons $2012-2013$ in comparison with the period 1986-2009. QuaGeo 2016, 35, 39-50. [CrossRef]

43. Hu, Y.; Xie, G.; Jiang, X.; Shao, K.; Tang, X.; Gao, G. The relationships between the free-living and particle-attached bacterial communities in response to elevated eutrophication. Front. Microbiol. 2020, 11, 423. [CrossRef]

44. Schimel, J.P. Life in dry soils: Effects of drought on soil microbial communities and processes. Annu. Rev. Ecol. Evol. Syst. 2018, 49, 409-432. [CrossRef]

45. Manzanera, M. Dealing with water stress and microbial preservation. Environ. Microbiol. 2021, 23, 3351-3359. [CrossRef]

46. Brás, T.A.; Seixas, J.; Carvalhais, N.; Jagermeyr, J. Severity of drought and heatwave crop losses tripled over the last five decades in Europe. Environ. Res. Lett. 2021, 16, 065012. [CrossRef]

47. Singh, R.; Parihar, P.; Singh, M.; Bajguz, A.; Kumar, J.; Singh, S.; Singh, V.P.; Prasad, S.M. Uncovering potential applications of cyanobacteria and algal metabolites in biology, agriculture and medicine: Current status and future prospects. Front. Microbiol. 2017, 8, 515. [CrossRef]

48. Camaille, M.; Fabre, N.; Clément, C.; Barka, E.A. Advances in wheat physiology in response to drought and the role of plant growth promoting rhizobacteria to trigger drought tolerance. Microorganisms 2021, 9, 687. [CrossRef]

49. Rysiak, A.; Dresler, S.; Hanaka, A.; Hawrylak-Nowak, B.; Strzemski, M.; Kováčik, J.; Sowa, I.; Latalski, M.; Wójciak, M. High temperature alters secondary metabolites and photosynthetic efficiency in Heracleum sosnowskyi. Int. J. Mol. Sci. 2021, $22,4756$. [CrossRef]

50. Abdelaal, K.; Alkahtani, M.; Attia, K.; Hafez, Y.; Király, L.; Künstler, A. The role of plant growth-promoting bacteria in alleviating the adverse effects of drought on plants. Biology 2021, 10, 520. [CrossRef] [PubMed]

51. Fang, Y.; Xiong, L. General mechanisms of drought response and their application in drought resistance improvement in plants. Cell. Mol. Life Sci. 2015, 72, 673-689. [CrossRef] [PubMed]

52. Luo, W.; Xu, C.; Ma, W.; Yue, X.; Liang, X.; Zuo, X.; Knapp, A.K.; Smith, M.D.; Sardans, J.; Dijkstra, F.A.; et al. Effects of extreme drought on plant nutrient uptake and resorption in rhizomatous vs bunchgrass-dominated grasslands. Oecologia 2018, 188, 633-643. [CrossRef] [PubMed]

53. Manavalan, L.P.; Guttikonda, S.K.; Phan Tran, L.S.; Nguyen, H.T. Physiological and molecular approaches to improve drought resistance in soybean. Plant Cell Physiol. 2009, 50, 1260-1276. [CrossRef] [PubMed]

54. Shao, H.B.; Chu, L.Y.; Jaleel, C.A.; Zhao, C.X. Water-deficit stress-induced anatomical changes in higher plants. Comptes Rendus Biol. 2008, 331, 215-225. [CrossRef]

55. Reddy, A.R.; Chaitanya, K.V.; Vivekanandan, M. Drought-induced responses of photosynthesis and antioxidant metabolism in higher plants. J. Plant Physiol. 2004, 161, 1189-1202. [CrossRef]

56. Abdelaal, K.A.A.; Hafez, Y.M.; El-Afry, M.M.; Tantawy, D.S.; Alshaal, T. Effect of some osmoregulators on photosynthesis, lipid peroxidation, antioxidative capacity, and productivity of barley (Hordeum vulgare L.) under water deficit stress. Environ. Sci. Pollut. Res. 2018, 25, 30199-30211. [CrossRef] [PubMed]

57. Hafez, Y.; Attia, K.; Alamery, S.; Ghazy, A.; Al-Doss, A.; Ibrahim, E.; Rashwan, E.; El-Maghraby, L.; Awad, A.; Abdelaal, K. Beneficial effects of biochar and chitosan on antioxidative capacity, osmolytes accumulation, and anatomical characters of water-stressed barley plants. Agronomy 2020, 10, 630. [CrossRef]

58. Hargravei, K.R.; Kolb, K.J.; Ewers, F.W.; Davis, S.D. Conduit diameter and drought-induced embolism in Salvia mellifera Greene (Labiatae). New Phytol. 1994, 126, 695-705. [CrossRef]

59. Liu, F.; Jensen, C.R.; Shahanzari, A.; Andersen, M.N.; Jacobsen, S.E. ABA regulated stomatal control and photosynthetic water use efficiency of potato (Solanum tuberosum L.) during progressive soil drying. Plant Sci. 2005, 168, 831-836. [CrossRef]

60. Ullah, A.; Mushtaq, H.; Fahad, S.; Hakim; Shah, A.; Chaudhary, H.J. Plant growth promoting potential of bacterial endophytes in novel association with Olea ferruginea and Withania coagulans. Microbiology 2017, 86, 119-127. [CrossRef]

61. Hussain, H.A.; Hussain, S.; Khaliq, A.; Ashraf, U.; Anjum, S.A.; Men, S.; Wang, L. Chilling and drought stresses in crop plants: Implications, cross talk, and potential management opportunities. Front. Plant Sci. 2018, 9, 393. [CrossRef]

62. Ragel, P.; Raddatz, N.; Leidi, E.O.; Quintero, F.J.; Pardo, J.M. Regulation of $\mathrm{K}^{+}$nutrition in plants. Front. Plant Sci. $2019,10,281$. [CrossRef]

63. Wang, Z.; Li, G.; Sun, H.; Ma, L.; Guo, Y.; Zhao, Z.; Gao, H.; Mei, L. Effects of drought stress on photosynthesis and photosynthetic electron transport chain in young apple tree leaves. Biol. Open 2018, 7. [CrossRef]

64. Zhang, Y.B.; Yang, S.L.; Dao, J.M.; Deng, J.; Shahzad, A.N.; Fan, X.; Li, R.D.; Quan, Y.J.; Bukhari, S.A.H.; Zeng, Z.H. Droughtinduced alterations in photosynthetic, ultrastructural and biochemical traits of contrasting sugarcane genotypes. PLoS ONE 2020, 15, e0235845. [CrossRef]

65. Cruz de Calvadio, M.H. Drought stress and reactive oxygen species. Plant Signal. Behav. 2008, 3, 156-165. [CrossRef]

66. Verma, G.; Srivastava, D.; Tiwari, P.; Chakrabarty, D. Reactive oxygen, nitrogen and sulfur species in plants: Production, metabolism, signaling and defense mechanisms. ROS modulation in crop plants under drought stress. In Reactive Oxygen, Nitrogen and Sulfur Species in Plants: Production, Metabolism, Signaling and Defense Mechanisms; Hasanuzzaman, M., Fotopoulos, V., Nahar, K., Fujita, M., Eds.; Wiley: Hoboken, NJ, USA, 2019; pp. 311-336.

67. Petrov, V.; Hille, J.; Mueller-Roeber, B.; Gechev, T.S. ROS-mediated abiotic stress-induced programmed cell death in plants. Front. Plant Sci. 2015, 6, 1-16. [CrossRef] 
68. Thakur, M.; Sohal, B.S. Role of elicitors in inducing resistance in plants against pathogen infection: A review. ISRN Biochem. 2013, 2013, 1-10. [CrossRef]

69. Ali, S.; Khan, N. Delineation of mechanistic approaches employed by plant growth promoting microorganisms for improving drought stress tolerance in plants. Microbiol. Res. 2021, 249, 126771. [CrossRef] [PubMed]

70. Vardharajula, S.; Ali, S.Z.; Grover, M.; Reddy, G.; Bandi, V. Drought-tolerant plant growth promoting Bacillus spp.: Effect on growth, osmolytes, and antioxidant status of maize under drought stress. J. Plant Interact. 2011, 6, 1-14. [CrossRef]

71. Jamiołkowska, A. Natural compounds as elicitors of plant resistance against diseases and new biocontrol strategies. Agronomy 2020, 10, 173. [CrossRef]

72. Walters, D.; Newton, A.; Lyon, G. (Eds.) Induced Resistance for Plant Defence. A Sustainable Approach to Crop Protection; Blackwell Publishing: Oxford, UK, 2007; ISBN 978-1-4051-3447-7.

73. Conrath, U.; Beckers, G.J.; Flors, V.; Garcia-Augustin, P.; Jakab, G.; Mauch, F.; Newman, M.-A.; Pieterse, C.M.J.; Poinssot, B.; Pozo, M.J.; et al. Priming: Getting ready for battle. Mol. Plant Microbe Interact. 2006, 19, 1062-1071. [CrossRef] [PubMed]

74. Martinez-Medina, A.; Flors, V.; Heil, M.; Mauch-Mani, B.; Pieterse, C.M.; Pozo, M.J.; Ton, J. Recognizing plant defense priming. Trends Plant Sci. 2016, 21, 818-822. [CrossRef]

75. Koziara, W.; Sulewska, H.; Panasiewicz, K. Effect of resistance stimulator application to some agricultural crops. J. Res. Appl. Agric. Eng. 2006, 51, 82-86.

76. Babosha, A.V. Changes in lectin activity in plants treated with resistance inducers. Plant Physiol. 2004, 31, 51-55. [CrossRef]

77. Jones, J.D.G.; Dangl, J.L. The plant immune system. Nature 2006, 444, 323-329. [CrossRef] [PubMed]

78. Boller, T.; Felix, G. A renaissance of elicitors: Perception of microbe-associated molecular patterns and danger signals by pattern-recognition receptors. Annu. Rev. Plant Biol. 2009, 60, 379-407. [CrossRef] [PubMed]

79. Henry, G.; Thonart, P.; Ongena, M. PAMPs, MAMPs, DAMPs and others: An update on the diversity of plant immunity elicitors. Biotechnol. Agron. Soc. Environ. 2012, 16, 257-268.

80. Schwessinger, B.; Ronald, P.C. Plant innate immunity: Perception of conserved microbial signatures. Annu. Rev. Plant Biol. 2012, 63, 451-482. [CrossRef]

81. Ranf, S. Sensing of molecular patterns through cell surface immune receptors. Curr. Opin. Plant Biol. 2017, 38, 68-77. [CrossRef]

82. Bigeard, J.; Colcombet, J.; Hirt, H. Signaling mechanisms in pattern-triggered immunity (PTI). Mol. Plant 2015, 8, 521-539. [CrossRef]

83. Wang, C.J.; Yang, W.; Wang, C.; Gu, C.; Niu, D.D.; Liu, H.X.; Wang, Y.P.; Guo, J.H. Induction of drought tolerance in cucumber plants by a consortium of three plant growth-promoting Rhizobacterium strains. PLoS ONE 2012, 7, e52565. [CrossRef]

84. Shrivastava, P.; Kumar, R. Soil salinity: A serious environmental issue and plant growth promoting bacteria as one of the tools for its alleviation. Saudi J. Biol. Sci. 2015, 22, 123-131. [CrossRef]

85. Singh, H.B.; Keswani, C.; Reddy, M.S.; Sansinenea, E.; García-Estrada, C. Secondary Metabolites of Plant Growth Promoting Rhizomicroorganisms: Discovery and Applications; Springer: Singapore, 2019; ISBN 9789811358623.

86. Oszust, K.; Pylak, M.; Frac, M. Trichoderma-based biopreparation with prebiotics supplementation for the naturalization of raspberry plant rhizosphere. J. Mol. Sci. 2021, 22, 6356. [CrossRef]

87. Timmusk, S.; Behers, L.; Muthoni, J.; Muraya, A.; Aronsson, A.C. Perspectives and challenges of microbial application for crop improvement. Front. Plant Sci. 2017, 8, 49. [CrossRef]

88. Sokolova, M.G.; Akimova, G.; Vaishlya, O.; Vedernikova, A. Physiological research of efficiency of biologically safe bacterial fertilizers. J. Manuf. Technol. Manag. 2010, 21, 956-970. [CrossRef]

89. Abd El-Gleel Mosa, W.F.; Paszt, L.S.; Frąc, M.; Trzciński, P.; Treder, W.; Klamkowski, K. The role of biofertilizers in improving vegetative growth, yield and fruit quality of apple. Hortic. Sci. 2018, 45, 173-180. [CrossRef]

90. Anli, M.; Baslam, M.; Tahiri, A.; Raklami, A.; Symanczik, S.; Boutasknit, A.; Ait-El-Mokhtar, M.; Ben-Laouane, R.; Toubali, S.; Ait Rahou, Y.; et al. Biofertilizers as strategies to improve photosynthetic apparatus, growth, and drought stress tolerance in the date palm. Front. Plant Sci. 2020, 11, 516818. [CrossRef] [PubMed]

91. Aseri, G.K.; Jain, N.; Panwar, J.; Rao, A.V.; Meghwal, P.R. Biofertilizers improve plant growth, fruit yield, nutrition, metabolism and rhizosphere enzyme activities of pomegranate (Punica granatum L.) in Indian Thar Desert. Sci. Hortic. 2008, 117, 130-135. [CrossRef]

92. Cipriano, M.A.P.; Lupatini, M.; Lopes-Santos, L.; da Silva, M.J.; Roesch, L.F.W.; Destéfano, S.A.L.; Freitas, S.S.; Kuramae, E.E. Lettuce and rhizosphere microbiome responses to growth promoting Pseudomonas species under field conditions. FEMS Microbiol. Ecol. 2016, 92, fiw197. [CrossRef]

93. Niu, X.; Song, L.; Xiao, Y.; Ge, W. Drought-tolerant plant growth-promoting rhizobacteria associated with foxtail millet in a semi-arid and their potential in alleviating drought stress. Front. Microbiol. 2018, 8, 2580. [CrossRef] [PubMed]

94. Astorga-Eló, M.; Gonzalez, S.; Acuña, J.J.; Sadowsky, M.J.; Jorquera, M.A. Rhizobacteria from 'flowering desert' events contribute to the mitigation of water scarcity stress during tomato seedling germination and growth. Sci. Rep. 2021, 11, 13745. [CrossRef]

95. Milet, A.; Chaouche, N.K.; Dehimat, L.; Kaki, A.A.; Mounira, K.A.; Philippe, T. Flow cytometry approach for studying the interaction between Bacillus mojavensis and Alternaria alternata. Afr. J. Biotechnol. 2016, 15, 1417-1428. [CrossRef]

96. Xie, Z.; Chu, Y.; Zhang, W.; Lang, D.; Zhang, X. Bacillus pumilus alleviates drought stress and increases metabolite accumulation in Glycyrrhiza uralensis Fisch. Environ. Exp. Bot. 2019, 158, 99-106. [CrossRef] 
97. Li, Y.; Shi, H.; Zhang, H.; Chen, S. Amelioration of drought effects in wheat and cucumber by the combined application of super absorbent polymer and potential biofertilizer. PeerJ 2019, 7, e6073. [CrossRef]

98. Asghari, B.; Khademian, R.; Sedaghati, B. Plant growth promoting rhizobacteria (PGPR) confer drought resistance and stimulate biosynthesis of secondary metabolites in pennyroyal (Mentha pulegium L.) under water shortage condition. Sci. Hortic. 2020, 263, 109132. [CrossRef]

99. Calvo-Polanco, M.; Sánchez-Romera, B.; Aroca, R.; Asins, M.J.; Declerck, S.; Dodd, I.C.; Martínez-Andújar, C.; Albacete, A.; Ruiz-Lozano, J.M. Exploring the use of recombinant inbred lines in combination with beneficial microbial inoculants (AM fungus and PGPR) to improve drought stress tolerance in tomato. Environ. Exp. Bot. 2016, 131, 47-57. [CrossRef]

100. Behrooz, A.; Vahdati, K.; Rejali, F.; Lotfi, M.; Sarikhani, S.; Leslie, C. Arbuscular mycorrhiza and plant growth-promoting bacteria alleviate drought stress in walnut. HortScience 2019, 54, 1087-1092. [CrossRef]

101. Kumar, M.; Mishra, S.; Dixit, V.; Kumar, M.; Agarwal, L.; Chauhan, P.S.; Nautiyal, C.S. Synergistic effect of Pseudomonas putida and Bacillus amyloliquefaciens ameliorates drought stress in chickpea (Cicer arietinum L.). Plant Signal. Behav. 2016, 11. [CrossRef] [PubMed]

102. Sandhya, V.; Ali, S.Z.; Grover, M.; Reddy, G.; Venkateswarlu, B. Effect of plant growth promoting Pseudomonas spp. on compatible solutes, antioxidant status and plant growth of maize under drought stress. Plant Growth Regul. 2010, 62, 21-30. [CrossRef]

103. Sarma, R.K.; Saikia, R. Alleviation of drought stress in mung bean by strain Pseudomonas aeruginosa GGRJ21. Plant Soil 2014, 377, 111-126. [CrossRef]

104. Roberson, E.B.; Firestone, M.K. Relationship between desiccation and exopolysaccharide production in a soil Pseudomonas sp. Appl. Environ. Microbiol. 1992, 58, 1284-1291. [CrossRef] [PubMed]

105. Mariotti, L.; Scartazza, A.; Curadi, M.; Picciarelli, P.; Toffanin, A. Azospirillum baldaniorum sp245 induces physiological responses to alleviate the adverse effects of drought stress in purple basil. Plants 2021, 10, 1141. [CrossRef]

106. Vettori, L.; Russo, A.; Felici, C.; Fiaschi, G.; Morini, S.; Toffanin, A. Improving micropropagation: Effect of Azospirillum brasilense Sp245 on acclimatization of rootstocks of fruit tree. J. Plant Interact. 2010, 5, 249-259. [CrossRef]

107. Heidari, M.; Mousavinik, S.M.; Golpayegani, A. Plant growth promoting Rhizobacteria (PGPR) effect on physiological parameters and mineral uptake in basil (Ociumum basilicum L.) under water stress. ARPN J. Agric. Biol. Sci. 2011, 6, 6-11.

108. Jones, P.D.; Lister, D.H.; Jaggard, K.W.; Pidgeon, J.D. Future climate impact on the productivity of sugar beet (Beta vulgaris L.) in Europe. Clim. Chang. 2003, 58, 98-103. [CrossRef]

109. Gauvry, E.; Mathot, A.-G.; Leguérinel, I.; Couvert, O.; Postollec, F.; Broussolle, V.; Coroller, L. Knowledge of the physiology of spore-forming bacteria can explain the origin of spores in the food environment. Res. Microbiol. 2016, 168, 369-378. [CrossRef]

110. Radhakrishnan, R.; Hashem, A.; Abd Allah, E.F. Bacillus: A biological tool for crop improvement through bio-molecular changes in adverse environments. Front. Physiol. 2017, 8, 667. [CrossRef] [PubMed]

111. Prajakta, B.M.; Suvarna, P.P.; Raghvendra, S.P.; Alok, R.R. Potential biocontrol and superlative plant growth promoting activity of indigenous Bacillus mojavensis PB-35 (R11) of soybean (Glycine max) rhizosphere. SN Appl. Sci. 2019, 1, 1143. [CrossRef]

112. Wang, C.; Guo, Y.; Wang, C.; Liu, H.; Niu, D.; Wang, Y.; Guo, J. Enhancement of tomato (Lycopersicon esculentum) tolerance to drought stress by plant-growth-promoting rhizobacterium (PGPR) Bacillus cereus AR. J. Agric. Biotechnol. 2012, 20, $1097-1105$.

113. Lim, J.H.; Kim, S.D. Induction of drought stress resistance by multi-functional PGPR Bacillus licheniformis K11 in pepper. Plant Pathol. J. 2013, 29, 201-208. [CrossRef]

114. Kaushal, M.; Wani, S.P. Plant-growth-promoting rhizobacteria: Drought stress alleviators to ameliorate crop production in drylands. Ann. Microbiol. 2016, 66, 35-42. [CrossRef]

115. Arkhipova, T.N.; Prinsen, E.; Veselov, S.U.; Martinenko, E.V.; Melentiev, A.I.; Kudoyarova, G.R. Cytokinin producing bacteria enhance plant growth in drying soil. Plant Soil 2007, 292, 305-315. [CrossRef]

116. Kramer, S.; Green, D.M. Acid and alkaline phosphatase dynamics and their relationship to soil microclimate in a semiarid woodland. Soil Biol. Biochem. 2000, 32, 179-188. [CrossRef]

117. Omer, A.M. Bioformulations of Bacillus spores for using as biofertilizer biovalorization of olive mill waste water for the production of natural biofertilizers and antioxidants view project isolation and identification of fungi and bacteria from different Egyptian e. Life Sci. J. 2010, 7, 1097-8135.

118. O'Hara, G.W.; Boonkerd, N.; Dilworth, M.J. Mineral constraints to nitrogen fixation. Plant Soil 1988, 108, 93-110. [CrossRef]

119. Xu, X.; Du, X.; Wang, F.; Sha, J.; Chen, Q.; Tian, G.; Zhu, Z.; Ge, S.; Jiang, Y. Effects of potassium levels on plant growth, accumulation and distribution of carbon, and nitrate metabolism in apple Dwarf Rootstock seedlings. Front. Plant Sci. 2020, 11, 904. [CrossRef] [PubMed]

120. Avakyan, Z.A. Silicon compounds in solution bacteria quartz degradation. Mikrobiologiya 1984, 54, 301-307.

121. Malinovskaya, I.M.; Kosenko, L.V.; Votselko, S.K.; Podgorsky, V.S. The role of Bacillus mucilaginosus polysaccharide in the destruction of silicate minerals. Mikrobiologiya 1990, 59, 70-78.

122. Barnawal, D.; Maji, D.; Bharti, N.; Chanotiya, C.S.; Kalra, A. ACC deaminase-containing Bacillus subtilis reduces stress ethyleneinduced damage and improves mycorrhizal colonization and rhizobial nodulation in Trigonella foenum-graecum under drought stress. J. Plant Growth Regul. 2013, 32, 809-822. [CrossRef]

123. Malusá, E.; Sas-Paszt, L.; Ciesielska, J. Technologies for beneficial microorganisms inocula used as biofertilizers. Sci. World J. 2012, 1-12. [CrossRef] 
124. Roberts, M.S.; Nakamura, L.K.; Cohan, F.M. Bacillus mojavensis sp. nov., distinguishable from Bacillus subtilis by sexual isolation, divergence in DNA sequence, and differences in fatty acid composition. Int. J. Syst. Bacteriol. 1994, 44, 256-264. [CrossRef] [PubMed]

125. Cao, L.; Qiu, Z.; You, J.; Tan, H.; Zhou, S. Isolation and characterization of endophytic Streptomyces strains from surface-sterilized tomato (Lycopersicon esculentum) roots. Lett. Appl. Microbiol. 2004, 39, 425-430. [CrossRef]

126. Moussa, T.A. Studies on biological control of sugar beet pathogen Rhizoctonia solani Kühn. J. Biol. Sci. 2002, 2, 800-804.

127. Snook, M.E.; Mitchell, T.; Hinton, D.M.; Bacon, C.W. Isolation and characterization of Leu 7-surfactin from the endophytic bacterium Bacillus mojavensis RRC 101, a biocontrol agent for Fusarium verticillioides. J. Agric. Food Chem. 2009, 57, 4287-4292. [CrossRef]

128. Romano-Armada, N.; Yañez-Yazlle, M.F.; Irazusta, V.P.; Rajal, V.B.; Moraga, N.B. Potential of bioremediation and PGP traits in Streptomyces as strategies for bio-reclamation of salt-affected soils for agriculture. Pathogens 2020, 9, 117. [CrossRef] [PubMed]

129. Hamedi, J.; Mohammadipanah, F. Biotechnological application and taxonomical distribution of plant growth promoting actinobacteria. J. Ind. Microbiol. Biotechnol. 2015, 42, 157-171. [CrossRef]

130. Chitraselvi, R.P.E. Actinomycetes: Dependable tool for sustainable agriculture. Curr. Investig. Agric. Curr. Res. 2018, 1, 128-130. [CrossRef]

131. Lawlor, K.; Knight, B.P.; Barbosa-Jefferson, V.L.; Lane, P.W.; Lilley, A.K.; Paton, G.I.; McGrath, S.P.; O’Flaherty, S.M.; Hirsch, P.R. Comparison of methods to investigate microbial populations in soils under different agricultural management. FEMS Microbiol. Ecol. 2000, 33, 129-137. [CrossRef] [PubMed]

132. Pierzynski, G.M.; Vance, G.F.; Sims, J.T. Soils and Environmental Quality; Taylor and Francis: Boca Raton, FL, USA, 2005.

133. Khamna, S.; Yokota, A.; Peberdy, J.F.; Lumyong, S. Indole-3-acetic acid production by Streptomyces sp. isolated from some Thai medicinal plant rhizosphere soils. Eur. Asian J. Biosci. 2010, 4, 23-32. [CrossRef]

134. El-Tarabily, K.A. Promotion of tomato (Lycopersicon esculentum Mill.) plant growth by rhizosphere competent 1-aminocyclopropane1-carboxylic acid deaminase-producing Streptomycete Actinomycetes. Plant Soil 2008, 308, 161-174. [CrossRef]

135. Gopalakrishnan, S.; Srinivas, V.; Vidya, M.S.; Rathore, A. Plant growth-promoting activities of Streptomyces spp. in sorghum and rice. Springerplus 2013, 2,1-8. [CrossRef]

136. El-Sayed, S.F.; Hassan, H.A.; El-Mogy, M.M. Impact of bio- and organic fertilizers on potato yield, quality and tuber weight loss after harvest. Potato Res. 2015, 58, 67-81. [CrossRef]

137. Wahyudi, A.T.; Priyanto, J.A.; Afrista, R.; Kurniati, D.; Astuti, R.I.; Akhdiya, A. Plant growth promoting activity of Actinomycetes isolated from soybean rhizosphere. Online J. Biol. Sci. 2019, 19, 1-8. [CrossRef]

138. Tredici, P. Del Nitrogen fixation: The story of the Frankia symbiosis. Arnold Arbor. 1995, 55, 26-31.

139. Treseder, K.K.; Berlemont, R.; Allison, S.D.; Martiny, A.C. Drought increases the frequencies of fungal functional genes related to carbon and nitrogen acquisition. PLoS ONE 2018, 13, e0206441. [CrossRef] [PubMed]

140. Treseder, K.K.; Lennon, J.T. Fungal traits that drive ecosystem dynamics on land. Microbiol. Mol. Biol. Rev. 2015, 79, $243-262$. [CrossRef] [PubMed]

141. Jiménez-Arias, D.; García-Machado, F.J.; Morales-Sierra, S.; García-García, A.L.; Herrera, A.J.; Valdés, F.; Luis, J.C.; Borges, A.A. A beginner's guide to osmoprotection by biostimulants. Plants 2021, 10, 363. [CrossRef] [PubMed]

142. Hardoim, P.R.; van Overbeek, L.S.; Berg, G.; Pirttilä, A.M.; Compant, S.; Campisano, A.; Döring, M.; Sessitsch, A. The hidden world within plants: Ecological and evolutionary considerations for defining functioning of microbial endophytes. Microbiol. Mol. Biol. Rev. 2015, 79, 293-320. [CrossRef]

143. Verma, H.; Kumar, D.; Kumar, V.; Kumari, M.; Singh, S.K.; Sharma, V.K.; Droby, S.; Santoyo, G.; White, J.F.; Kumar, A. The potential application of endophytes in management of stress from drought and salinity in crop plants. Microorganisms 2021, 9, 1729. [CrossRef]

144. Bizos, G.; Papatheodorou, E.M.; Chatzistathis, T.; Ntalli, N.; Aschonitis, V.G.; Monokrousos, N. The role of microbial inoculants on plant protection, growth stimulation, and crop productivity of the olive tree (Olea europea L.). Plants 2020, 9, 743. [CrossRef]

145. Bona, E.; Lingua, G.; Manassero, P.; Cantamessa, S.; Marsano, F.; Todeschini, V.; Copetta, A.; D’Agostino, G.; Massa, N.; Avidano, L.; et al. AM fungi and PGP Pseudomonads increase flowering, fruit production, and vitamin content in strawberry grown at low nitrogen and phosphorus levels. Mycorrhiza 2015, 25, 181-193. [CrossRef]

146. Adamec, S.; Andrejiová, A. Mycorrhiza and stress tolerance of vegetables: A review. Acta Hortic. Regiotect. 2018, 21, 30-35. [CrossRef]

147. Marulanda, A.; Barea, J.M.; Azcón, R. Stimulation of plant growth and drought tolerance by native microorganisms (AM fungi and bacteria) from dry environments: Mechanisms related to bacterial effectiveness. J. Plant Growth Regul. 2009, $28,115-124$. [CrossRef]

148. Matias, S.R.; Pagano, M.C.; Muzzi, F.C.; Oliveira, C.A.; Carneiro, A.A.; Horta, S.N.; Scotti, M.R. Effect of rhizobia, mycorrhizal fungi and phosphate-solubilizing microorganisms in the rhizosphere of native plants used to recover an iron ore area in Brazil. Eur. J. Soil Biol. 2009, 45, 259-266. [CrossRef]

149. Dreischhoff, S.; Das, I.S.; Jakobi, M.; Kasper, K.; Polle, A. Local responses and systemic induced resistance mediated by ectomycorrhizal fungi. Front. Plant Sci. 2020, 11, 590063. [CrossRef] [PubMed]

150. De Battista, J.P.; Bacon, C.W.; Severson, R.; Plattner, R.D. Indole acetic acid production by the fungal endophyte of Tall Fescue. Agron. J. 1990, 82, 878-880. [CrossRef] 
151. Khan, A.L.; Waqas, M.; Khan, A.R.; Hussain, J.; Kang, S.M.; Gilani, S.A.; Hamayun, M.; Shin, J.H.; Kamran, M.; Al-Harrasi, A.; et al. Fungal endophyte Penicillium janthinellum LK5 improves growth of ABA-deficient tomato under salinity. World J. Microbiol. Biotechnol. 2013, 29, 2133-2144. [CrossRef] [PubMed]

152. Ren, A.; Clayy, K. Impact of a horizontally transmitted endophyte, Balansia henningsiana, on growth and drought tolerance of Panicum rigidulum. Int. J. Plant Sci. 2009, 170, 599-608. [CrossRef]

153. Dastogeer, K.M.G.; Li, H.; Sivasithamparam, K.; Jones, M.G.K.; Wylie, S.J. Fungal endophytes and a virus confer drought tolerance to Nicotiana benthamiana plants through modulating osmolytes, antioxidant enzymes and expression of host drought responsive genes. Environ. Exp. Bot. 2018, 149, 95-108. [CrossRef]

154. Davies, F.T.; Potter, J.R.; Linderman Davies, R.G.; Ft, R.; Linderman, R. Drought resistance of mycorrhizal pepper plants independent of leaf $\mathrm{P}$ concentration-response in gas exchange and water relations. Physiol. Plant. 1993, 87, 45-53. [CrossRef]

155. Liao, X.; Chen, J.; Guan, R.; Liu, J.; Sun, Q. Two arbuscular mycorrhizal fungi alleviates drought stress and improves plant growth in Cinnamomum migao seedlings. Mycobiology 2021, 49, 396-405. [CrossRef]

156. Azad, K.; Kaminskyj, S. A fungal endophyte strategy for mitigating the effect of salt and drought stress on plant growth. Symbiosis 2016, 68, 73-78. [CrossRef]

157. Sun, C.; Johnson, J.M.; Cai, D.; Sherameti, I.; Oelmüller, R.; Lou, B. Piriformospora indica confers drought tolerance in Chinese cabbage leaves by stimulating antioxidant enzymes, the expression of drought-related genes and the plastid-localized CAS protein. J. Plant Physiol. 2010, 167, 1009-1017. [CrossRef]

158. Morsy, M.; Cleckler, B.; Armuelles-Millican, H. Fungal endophytes promote tomato growth and enhance drought and salt tolerance. Plants 2020, 9, 877. [CrossRef]

159. Subramanian, K.S.; Santhanakrishnan, P.; Balasubramanian, P. Responses of field grown tomato plants to arbuscular mycorrhizal fungal colonization under varying intensities of drought stress. Sci. Hortic. 2006, 107, 245-253. [CrossRef]

160. Bae, H.; Sicher, R.C.; Kim, M.S.; Kim, S.H.; Strem, M.D.; Melnick, R.L.; Bailey, B.A. The beneficial endophyte Trichoderma hamatum isolate DIS 219b promotes growth and delays the onset of the drought response in Theobroma cacao. J. Exp. Bot. 2009, 60, 3279-3295. [CrossRef]

161. Wu, Q.S.; Xia, R.X.; Zou, Y.N. Improved soil structure and citrus growth after inoculation with three arbuscular mycorrhizal fungi under drought stress. Eur. J. Soil Biol. 2008, 44, 122-128. [CrossRef]

162. Thirumalai, E.; Venkatachalam, A.; Suryanarayanan, T.S. Fungal endophytes of betel leaves: The need to study mycotoxinproducing endophytes in leafy vegetables. Sydowia 2020, 73, 83-88. [CrossRef]

163. Carbone, M.J.; Alaniz, S.; Mondino, P.; Gelabert, M.; Eichmeier, A.; Tekielska, D.; Bujanda, R.; Gramaje, D. Drought influences fungal community dynamics in the grapevine rhizosphere and root microbiome. J. Fungi 2021, 7, 686. [CrossRef]

164. Piri, R.; Moradi, A.; Balouchi, H.; Salehi, A. Improvement of cumin (Cuminum cyminum) seed performance under drought stress by seed coating and biopriming. Sci. Hortic. 2019, 257, 108667. [CrossRef] 